\title{
Better to Burn Out than to Fade Away? Tax Consequences on the Disposition of a Tax Shelter
}

\author{
Joshua D. Rosenberg $†$
}

The Supreme Court recently granted certiorari in Tufts v. Commissioner. ${ }^{1}$ Even before the grant, the issues involved in Tufts had engendered interest and lively discussion among tax practitioners and scholars. $^{2}$ Simce the grant of certiorari, that interest has grown. ${ }^{3}$ The case involves the tax consequences to an individual who disposes of a "burned out" tax shelter. Because the shelter has provided significant tax benefits while the taxpayer has owned it, the Service ${ }^{4}$ and inost courts ${ }^{5}$ have decided that the taxpayer slould liave to account in soine way for these benefits upon disposal of the tax shelter. However, even with all the imterest and analysis surrounding Tufts, no one has suggested a satisfactory solution to the problem involved therein.

The problem involves taxpayers who purchase depreciable real property subject to a nonrecourse debt. If the property is worth more than the debt to which it is subject at the time of purchase, the debt will be treated as part of the taxpayer's cost for the property, and the taxpayer will be entitled to depreciation deductions based on that cost. If the property later declines in value below the amount of the nonrecourse debt, the taxpayer will not pay the debt. He will instead default on the debt and allow the mortgagee to foreclose on the property. When this occurs, the taxpayer will have deducted, as depreciation, an

$\dagger$ Assistant Professor of Law, University of San Francisco. B.A. 1971, Case Western Reserve University; J.D. 1974, New York University; LL.M. (Taxation) 1980, New York University.

1. 70 T.C. 756 (1978), rev'd, 651 F.2d 1058 (5th Cir. 1981), cert. granted, 102 S. Ct. 2034 (No. 81-1536).

2. E.g., Bittker, Tax Shelters, Nonrecourse Debt, and the Crane Case, 33 TAX L. REv. 277 (1978); Halpern, Footnote 37 and the Crane Case: The Problem That Never Really Was, 6 J. ReAL Est. TAX 197 (1979); Ginsburg, The Leaky Tax Shelier, 53 TAXES 719 (1975); Sexton \& Charyk, Liabilities in Excess of Fair Market Value: The Uncertain Scope of the Tufts Case, $6 \mathrm{~J}$. REAL EsT. TAX 251 (1979); Note, Requiem for Crane's Footnote 37?, 41 U. PITT. L. REv. 343 (1980).

3. E.g., Newman, The Resurgence of Footnote 37: Tufts v. Commissioner, 18 WAKE FoREST L. REV. 1 (1982).

4. Rev. Rul. 76-111, 1976-1 C.B. 214.

5. E.g., Millar v. Commissioner, 577 F.2d 212, 214-16 (3d Cir. 1978); Woodsam Assocs. v. Commissioner, 198 F.2d 357, 358-59 (2d Cir. 1952); Estate of Delman v. Commissioner, 73 T.C. 15, 29-30 (1979); Tufts, 70 T.C. at 763-66. 
amount includimg the nonrecourse mortgage, even though he has never actually paid that debt.

To counteract these unwarranted deductions, some courts and commentators would include the full nonrecourse mortgage in the taxpayer's amount realized on foreclosure. ${ }^{6}$ This im turn results im increased gain at the time of the foreclosure equal to the extra deductions generated by inclusion of the nonrecourse debt in the taxpayer's original cost basis. This approach is unsatisfactory. It distorts the basic concept of what an amount realized is; and it often allows the taxpayer the luxury of reporting capital gains on his disposition of the property even though he has used his depreciation deductions to offset ordmary income. Unfortunately, the only other approach to these unjustified deductions suggested to date has been to ignore them coinpletely. This Article suggests several solutions to the problem that are both more logical and more equitable.

Part I of this Article provides the legal background for discussion of the issues surrounding the Tufts case. Parts II and III propose alternative solutions to those the commentators and courts have so far provided. In particular, Part II proposes an expanded version of the tax benefit rule while Part III proposes the application of the rules regarding income from the discharge of indebtedness to the Tufts problem. Part IV then applies the proposed rules to variations on the basic fact pattern. Finally, Part V suggests that where both proposed rules may apply, the discharge of mdebtedness should take precedence.

\section{BACKGROUND}

This Part provides the background for later analysis of the tax of the disposition of property subject to nonrecourse debt. The effect of the purchase and later sale of property subject to nonrecourse debt will be described in a hypothetical that is similar to the facts in Tufts. Then, the Tufts case itself and the widely accepted solution to the problem will be examined. Finally, a different approach will be suggested.

\section{A. Inclusion of Nonrecourse Debt in Basis}

Pursuant to well establislied case law, ${ }^{7}$ when a taxpayer purchases property subject to a nonrecourse inortgage, the taxpayer's basis (cost) ${ }^{8}$ $\mathrm{m}$ the property mcludes the full anount of this nonrecourse debt. The

6. See infra notes 24-26 and accompanying text.

7. Crane v. Commissioner, 331 U.S. 1 (1947); Mayerson v. Commissioner, 47 T.C. 340 (1966), acq. 1969-1 C.B. 21.

8. I.R.C. $\S 1011$ (1976) provides that "[t]he adjusted basis for determining the gain or loss from the sale or other disposition of property, whenever acquired, shall be the basis (determined 
following hypothetical, which will be referred to throughout this Article, illustrates the result of this rule. Suppose $T$ buys depreciable real property worth $\$ 400,000$, and assume that the property is reasonably expected to retain its current value for five years. The taxpayer pays $\$ 20,000$ down and finances the remaining $\$ 380,000$ with a nonrecourse note from the seller secured by the property and payable in full at the end of five years. For all tax purposes, $T$ is the owner of the property. He may thus depreciate the property over its remaining useful life. ${ }^{9}$ His cost basis under section $1012^{10}$ includes the note, and is therefore $\$ 400,000$. Assuming he takes straight-line depreciation, " and assuming the property has a 20-year useful life, his depreciation deduction is $\$ 20,000$ per year (1/20 of his $\$ 400,000$ basis). Aside from any interest that he may pay and deduct currently, ${ }^{12} \mathrm{~T}$ will deduct $\$ 20,000$ depreciation each year, even though he has only paid a total of $\$ 20,000$ cash for the property. ${ }^{13}$ After five years, $T$ will have deducted $\$ 100,000$ of depreciation, which (assuming $\mathrm{T}$ is a $50 \%$ bracket taxpayer ${ }^{14}$ ) will have saved him $\$ 50,000$ in taxes. His tax savings will then be $250 \%$ of his total cash investment in the property. This tax savings is presumably justified by the assumption that the taxpayer will eventually pay the nonrecourse debt, so that the amounts deducted in depreciation will in fact only equal T's real out-of-pocket expenses.

\section{B. Tufts v. Commissioner: Disposition of Property Subject to a Nonrecourse Debt}

\section{The Case}

Tufts v. Commissioner involved taxpayers who purchased and took depreciation on real property subject to a nonrecourse mortgage, but never paid that debt. The taxpayers in Tufts formed a partnership that constructed an apartment complex in 1971. The partnership financed

under section 1012 . . )." I.R.C. $\S 1012$ (1976) states that "[t]he basis of property shall be the cost of such property, except as otherwise provided."

9. I.R.C. $§ 167$ (1976 \& Supp. IV 1980). For purchases made after December 31, 1980, depreciation deductions will be governed by I.R.C. $\S 168$, which permits depreciation over periods which may be substantially shorter than the actual remaining useful life. I.R.C. $\$ 168$ (Supp. V 1981). erty."

10. I.R.C. $\S 1012$ (1976) provides that the "basis of property shall be the cost of such prop-

11. I.R.C. § 167(b)(1) (1976 \& Supp. IV 1980).

12. I.R.C. \& 163(a) (1976).

13. I.R.C. \$ 465 (Supp. IV 1980) prevents most taxpayers from deducting losses from any activity im excess of the amount for which they are personally 'at risk,' imcluding primarily amounts they have paid or for which they are personally liable. I.R.C. \& 465(c)(3)(D) (Supp. IV 1980), however, exempts activities involving real property.

14. For purposes of this Article, all taxpayers are presumed to be in the highest marginal bracket. Generally, it is only high bracket taxpayers who purchase tax shelters. 
the entire cost of this construction with a nonrecourse mortgage of $\$ 1,851,500$, acquired from a savings and loan and secured by the apartment complex. In 1971 and 1972 each partner claimed depreciation deductions on the complex that amountcd to an aggregate total of $\$ 395,760$, and the basis of the property was decreased by the amount of depreciation taken, to $\$ 1,455,740$. In 1972 each partner transferred his partnership interest in the property to an unrelated third party. The purchaser took the property subject to the $\$ 1,851,500$ inortgage and agreed to pay the expenses incurred by the partners as a result of the sale, up to $\$ 250$; he paid no other consideration.

As a result of this transfer, the partners claimed a deductible long term capital loss of $\$ 55,740,{ }^{15}$ an amount equal to the excess of the adjusted basis of $\$ 1,455,740$ over the fair market value of $\$ 1,400,000$. The Tax Court, however, decided that the taxpayer had realized a gam of $\$ 395,760,{ }^{16}$ an amount equal to the excess of the $\$ 1,851,500$ nonrecourse debt to which the property has been subject over the taxpayers' adjusted basis of $\$ 1,455,740$. The disagreement between the Tax Court's decision and the taxpayers' claim stemmed from the fact that the Tax Court required the taxpayers to include the full amount of the nonrecourse debt in their amount realized upon disposition, ${ }^{17}$ while the taxpayers argued that their amount realized should not exceed the fair market value of the property transferred. ${ }^{18}$ On appeal, the Fifth Circuit agreed with the taxpayers' argument and reversed the Tax Court, holding that a taxpayer's amount realized on the disposition of property subject to nonrecourse debt cannot exceed the fair market value of that property. ${ }^{19}$

Application of the holdings of both the Tax Court and the court of appeals in Tufts to the facts of our hypothetical reveals that illogical and inequitable tax results will occur if either approach is followed. Under our hypothetical, if, during T's possession, the property which T purchased for $\$ 400,000$ has substantially declined in value, then after five years $T$ may have property worth only $\$ 200,000$ rather than his original cost of $\$ 400,000$. T will choose not to pay the $\$ 380,000$ debt secured by the property and instead will return the property to the seller-lender. In other words, T will transfer property worth $\$ 200,000$ in full satisfaction of the $\$ 380,000$ debt. The Fifth Circuit's holding in Tufts would lead to the following conclusions: (1) T's adjusted basis im the property at this juncture is $\$ 300,000$ (original cost basis of $\$ 400,000$

15. This amount of $\$ 55,740$ was not specifically referred to in $T u f t s$, but it is the excess of the property's adjusted basis over the property's fair market value.

16. 70 T.C. at 762 .

17. Id. at 770 .

18. Id. at 763 .

19. 651 F.2d at 1063. 
less adjustments for the $\$ 100,000$ depreciation claimed); ${ }^{20}$ (2) T's amount realized $^{21}$ is $\$ 200,000$, the fair market value of the property at the time of disposition; and (3) $\mathrm{T}$ has a long term capital loss of $\$ 100,000$ when he returns the property. ${ }^{22}$

\section{Criticism of the Fifth Circuit's Approach in Tufts and the Generally Accepted Alternative}

Intuitively, there seems to be something amiss in the above result. The taxpayer in our hypothetical has taken depreciation deductions of $\$ 100,000$ and as a result has saved $\$ 50,000$ in taxes during his ownership of the property. When he disposes of the property, he has a $\$ 100,000$ deductible long tern capital loss and saves an additional $\$ 20,000$ in taxes. ${ }^{23}$ Yet $T$ has still paid a total of only $\$ 20,000$ (the initial down payment). Thus, T's total cash outlay is $\$ 20,000$ (his down payment); his total tax savings are $\$ 70,000$; and $T$ is ahead $\$ 50,000$. This profit comes not from a good investment (the property was a bad investment, having declined from $\$ 400,000$ to $\$ 200,000$ in value), but from the United States Treasury.

The almost unanimous declaration of conmentators ${ }^{24}$ and courts, mcluding the Tax Court in Tufts, ${ }^{25}$ has been that the amount $T$ realizes on this disposition should include not just the fair n1arket value of the property at the time of disposition, but the full annount of the nonrecourse debt to which the property was then subject. Under this view, when $T$ disposes of the property, his amount realized is not $\$ 200,000$,

20. I.R.C. $\$ 1016(a)(2)$ (1976) provides that a taxpayer's basis be adjusted to reflect depreciation.

21. I.R.C. \& 1001(b) (1976).

22. I.R.C. \& 1222(4) (1976 \& Supp. IV 1980). The Fifth Circuit in Tufts permitted such a capital loss. 651 F.2d at 1061. Deductibility of the loss is limited, however, by I.R.C. $\S \S 165(\mathrm{f})$, 1211 (1976 \& Supp. IV 1980). Soine courts had held that the voluntary transfer of inortgaged property to the inortgagee in discharge of the debt was not a 'sale or exchange' of the property as required by I.R.C. $\S 1222(3)(1976)$ and produced ordinary gain or loss rather than a capital loss where the inortgagor was not personally liable. Stokes v. Commissioner, 124 F.2d 335, 337 (3d Cir. 1941); Polin v. Commissioner, 114 F.2d 174, 176 (3d Cir. 1940); Commissioner v. Hoffunan, 117 F.2d 987 (2d Cir. 1941). Since Crane, these cases, which distinguished between recourse and nonrecourse debt, have not been followed. Freeland v. Commissioner, 74 T.C. 970,982 (1980). An involuntary transfer to the mortgagee for a transfer to a third party lias always been treated as a sale or exchange generating capital gain or loss, e.g., Welch v. Street, 116 F.2d 953, 954 (1st Cir. 1941); Helvering v. Nebraska Bridge Supply and Lumber Co., 312 U.S. 666 (1941) (per curiam). It is assumed that the property is a capital asset for T within the meaning of I.R.C. $\$ 1221$ (1976).

23. The loss is deductible to the extent that $T$ has other long term capital gains that would otherwise be taxable at a 20\% rate but which are offset by his capital loss. I.R.C. $\S \S 165(\mathrm{f}), 1211(\mathrm{~b})$ (1976 \& Supp. IV 1980).

24. See Bittker, supra note 2, at 283-84; Halpern, supra note 2, at 216-21; Ginsburg, supra note 2, at 730-32; Newinan, supra note 3, at 7-13.

25. See Millar, 577 F.2d at 214-16; Woodsam, 198 F.2d at 358, Tufts, 70 T.C. at 770; Delman, 73 T.C. at $29-30$. 
but $\$ 380,000$. Instead of a $\$ 100,000$ long term capital loss on his disposition, resulting in added tax benefits, $T$ would have $\$ 80,000$ of taxable long term capital gain (amount realized of $\$ 380,000$ less adjusted basis of $\$ 300,000)$. Tax payable on this gain would be $\$ 16,000 .^{26}$ Thus, while $T$ saved $\$ 50,000$ in taxes through his deductions for depreciation, he will have to return $\$ 16,000$ of that savings when he disposes of the property, instead of being given additional tax savings.

\section{Criticism of the Tax Court's Approach in Tufts and A Suggested Approach}

While the efforts of courts and commentators to reach a result that is more equitable than that reached by the Fifth Circuit in Tufts are admirable, the results have not been. These efforts, as apphed, for example, by the Tax Court in Tufts, have focused only on one issue: "What is the taxpayer's amount realized when he disposes of the property?" The problein has been seen to lay in the taxpayer's assertion that his amount realized cannot exceed the fair inarket value of the property disposed of, and the solution has been seen to lay in arguing that his amount realized must include the full amount of the nonrecourse debt to which the property was subject. The result of this focus has been a distortion of the concept of anount realized and a concerted disregard of previous Supreme Court statements. The Fifth Circuit's limitation of the amount realized in Tufts has been erroneously seen as a point of contention rather than, as it should be, a point of einbarcation.

\section{a. Amount Realized: The Basic Concept and Crane v. Commissioner Revisited}

A taxpayer's amount realized from the sale or other disposition of property is defined as "the sum of any money received plus the fair inarket value of the property (other than money) received." 27 Obviously, if a taxpayer holds property subject to a nonrecourse inortgage in excess of the value of the property, he will receive neither money nor property when he abandons the property to the mortgagee. The Supreme Court, however, has long held that a taxpayer inay receive taxable benefits other than the actual receipt of inoney or property. ${ }^{28}$ If these benefits are received in exchange for property, they are included in the taxpayer's amount realized for that property. One such taxable

26. Assuming $\mathrm{T}$ is a $50 \%$ bracket taxpayer, the deduction for long term capital gains granted by I.R.C. $\S 1202$ (Supp. IV 1980) will result in an effective $20 \%$ rate on those gains.

27. 1.R.C. $\$ 1001$ (b) (1976).

28. Crane, 331 U.S. at 13; Umited States v. Hendler, 303 U.S. 564, 566 (1938); see Diedrich v. Commissioner, 102 S. Ct. 2414, 2417 (1982). 
benefit may be the discharge of a taxpayer's personal liability by another party. The Court has stated that where a taxpayer's personal liability is discharged by a third party, the taxpayer is the " 'beneficiary" of the payment 'in as real and substantial [a sense] as if the money had been paid [to the taxpayer] and then paid over by it to its creditors." "29

The idea that being relieved of a personal debt inay be the equivalent of receiving cash equal to the ainount of the debt was seized upon by the Supreme Court in Crane v. Commissioner. ${ }^{30}$ In Crane, the Court applied this idea to a situation where, as in Tufts and in our hypothetical, the taxpayer was not relieved of a personal liability, but was relieved only of a nonrecourse obligation. Ms. Crane had held property subject to a nonrecourse mortgage of approximately $\$ 255,000$. She sold the property for $\$ 2,500 \mathrm{cash}$, the purchaser taking subject to the nonrecourse mortgage. The Court found that since Ms. Crane received $\$ 2,500$ cash on her sale, she must have had an equity of $\$ 2,500$ in the property. The only way Ms. Crane could have protected her $\$ 2,500$ equity was by seeing to it that the mortgage was not foreclosed. Thus, Ms. Crane was required to treat the nonrecourse debt as if it were her own personal debt in order to protect her equity in the property. The Court held that when the purchaser took the property subject to the $\$ 255,000$ mortgage, Ms. Crane benefited by being reheved of the debt that she would have treated as a personal liability. ${ }^{31}$ As a result, Ms. Crane's amount realized imcluded the amount of the nonrecourse hability from which she was relieved.

In its now famous footnote 37, the Court stated: "Obviously, if the value of the property is less than the amount of the mortgage, a mortgagor who is not personally liable cannot realize a benefit equal to the inortgage ... . That is not this case."32 This footnote, though wellknown, had until the Fifth Circuit's decision in Tufts been ignored by the courts. When courts faced this question they had uniformly held that, regardless of the value of the property subject to the nonrecourse debt, the taxpayer's amount realized on the disposition of that property imcluded the full ainount of the debt. ${ }^{33}$

In spite of the courts' stubbornness, the reasonableness of footnote 37's conclusion cannot be doubted. A taxpayer's amount realized is the amount that he gets in exchange for his property. If he gets cash, other property, or has his personal obhgation discharged in exchange for his

29. Crane, 331 U.S. at 13 (quoting Handler, 303 U.S. at 566).

30. 331 U.S. at 13.

31. Id. at $13,14$.

32. Id. at 14.

33. E.g., Millar, 577 F.2d at 214-16; Woodsam, 198 F.2d at 358; Delman, 73 T.C. at 29-30; Tufts, 70 T.C. at 770. 
property, his amount realized imcludes the cash, the value of the property, or the value of the debt rehef he receives. While value received may take numerous forms, it is only the actual value received, whatever form it takes, that constitutes the taxpayer's amount realized. If a taxpayer holds property subject to a nonrecourse mortgage in excess of the property's value, he still will not receive inore than that property's value when he disposes of it.

To illustrate, if a taxpayer holds property worth $\$ 400,000$ and subject to a nonrecourse debt of $\$ 380,000$, he will pay that debt in order to protect his equity in the property. If he is reheved of that debt, he is benefited to the extent of the $\$ 380,000$ he had owed, and that benefit is included in his amount realized. If, however, the taxpayer holds property worth $\$ 200,000$ subject to a nonrecourse debt of $\$ 380,000$, he will not pay that debt. Simce he is not personally liable, he simply will not pay $\$ 380,000$ to keep property worth little more than half that amount. Since he would not pay the $\$ 380,000$, he will not receive a $\$ 380,000$ benefit when he is reheved of that obligation.

Even though the taxpayer could not be expected to treat the $\$ 380,000$ as a personal habhty, the inortgage is nonetheless of import to him because if he does not pay the cash, he must at least be willing to sacrifice the encumbered property, worth $\$ 200,000$. In other words, a taxpayer with property subject to a nonrecourse mortgage will have to part with the lesser in value of (1) cash equal to the mortgage, or (2) the encumbered property itself. If the property is worth $\$ 200,000$ and the mortgage is $\$ 380,000$, the taxpayer will part with the property worth $\$ 200,000$ im order to satisfy the mortgage. When the taxpayer disposes of the property in which he has no equity, he gives up property worth $\$ 200,000$. In exchange, he is simultaneously reheved of his obhigation to pay off the mortgage. The burden from which he was relieved was the obligation to return property worth $\$ 200,000$. Since his amount realized imcludes no cash or property actually received, it must include only the amount constructively received-that is, the discharge of his obligation to return $\$ 200,000$ worth of property.

No one will give the taxpayer more than the value of his property merely in exchange for that property. The taxpayer receives no other benefit in excess of that value when he relieves himself of the property and its accompanying burden. To suggest that his amount realized exceeds that value is to suggest that somehow his amount realized in exchange for his property imcludes more than the total benefits he receives for his property. Such a notion is contrary to the most basic primciples of taxation. 


\section{b. A Broader Approach Is Needed}

To concede that the taxpayer's amount realized on the sale or exchange of his property does not exceed the fair market value of the property disposed of is not to concede that the taxpayer has no tax liability on his disposition of the mortgaged property. Instead, this initial concession simply paves the way for an understanding that taxable income from any given transaction need not be limited by the seller's amount realized. Indeed, as will be seen, a proper concession that the mortgagor's amount realized is limited to the fair market value of the mortgaged property can lead to an increase in his tax liability over that yielded by the Tax Court's approach, because it will lead to the conclusion that the excess of nonrecourse debt ( $\$ 380,000 \mathrm{im}$ our lyypothetical) over the fair inarket value of the property is not part of the taxpayer's amount realized and does not produce long term capital gam, taxed at a $20 \%$ rate, but is in whole or im part taxable as ordinary income subject to tax at the $50 \%$ rate. Instead of allowing $T$ to save $\$ 50,000$ in taxes while he holds the property, and to repay only $\$ 16,000$ on his disposition, the approach suggested here will tend to equate the anount $T$ pays when he disposes of that property with the amount he has saved while he held the property - a result that is both logical and equitable.

II

\section{The TAX Benefit Rule}

Most courts have used a tax benefit approacli to justify inclusion of nonrecourse debt in a taxpayer's amount realized. They have reasoned that since the nonrecourse debt was included in the taxpayer's cost basis, if the debt is not paid, it should also be included in his amount realized. ${ }^{34}$ This result, however, comports with neither the letter nor the spirit of the actual tax benefit rule. Under the tax benefit rule, if a taxpayer pays or accrues a deductible expense and the payment is later returned to him, or the accrued expense is not actually paid, the taxpayer has gross income equal in amount and character to the amount previously deducted. The approach adopted by the courts, such as the Tax Court in Tufts, fails to produce an amount of incoine of the saine character as the amount of the unpaid but accrued deductions, and fails to include any amount im ordinary income, because the courts include it in ainount realized instead.

Part II considers and proposes several other nore appropriate applications of the tax benefit rule to the problem presented by Tufts and our hypothetical. These applications focus on the proper treatment of accorned but unpaid tax benefits, to which the tax benefit rule has his-

34. See supra note 25 and accompanying text. 
torically been addressed, rather than on some vague notion of tax benefit "principles" that bears no relation to the tax benefit rule itself. The suggested applications all require that the amounts that have been deducted in the forn of depreciation, but that were never actually paid, be imcluded in the taxpayer's gross income (as opposed to amount realized) upon his disposition of the property.

More than one possible apphication of the rule exists because there are two questions imvolved: (1) how much has $\mathrm{T}$ actually deducted but never paid; and (2) may the tax benefit rule be applied to require inclusion in gross imcome of amounts that have not been deducted but that have produced other tax benefits. The answers to these questions dictate both the amount and the character of the income generated by the tax benefit rule. The answers suggested herem produce an amount of income equal to the amount of depreciation taken and not actually paid, and the income is characterized just as Congress intended it to be when it enacted section 1250 of the Code, which governs the character of gam on the disposition of depreciable real property.

\section{A. Previous Suggested Applications}

As noted, courts and commentators have suggested that tax benefit principles require the inclusion of the entire nonrecourse debt in the taxpayer's amount realized. ${ }^{35}$ This is a result of a misreading of the Crane case, and it in turn results in a substantial and undeserved reward to the taxpayer who disposes of excessively mortgaged property and thereby converts ordinary income into capital gam. This did not occur in Crane, and should not occur in any other case, simce none of the reasons for the favorable treatment of capital gams apply to the Tufts situation and no other established tax principle could support such treatment.

\section{How the Rule Has Been Used}

Faced with a definition of "amount realized" that seems to exclude from its ambit any nonrecourse debt in excess of the property's fair market value, courts and commentators have been forced to search elsewhere for a solution to the problem of how to tax the disposition of encumbered property. Most, imcluding the Tax Court, the Second Circuit and the Third Circuit, ${ }^{36}$ have stopped looking when they found the "tax (or economic) benefit" concept.

Simply stated, the idea of tax benefit adopted by the courts suggests that simce a taxpayer benefits by mcluding nonrecourse debt in his

35. See supra text accompanying notes 24-26.

36. Millar, 577 F.2d at 214-16, Woodsam, 198 F.2d at 358, Delman, 73 T.C. at 29-30. 
original cost basis, he should be required to repay the system by also including the nonrecourse debt in his amount realized. ${ }^{37}$ If, in our example, the nonrecourse debt had not been included in T's basis, his original cost basis would have been $\$ 20,000$ instead of $\$ 400,000$. Assuming the saine 20-year useful life and straight-line depreciation, $T$ could have deducted only $\$ 1,000$ per year in depreciation, instead of the $\$ 20,000$ per year that he did in fact deduct. Since $T$ benefited (to the extent of $\$ 19,000$ per year of extra depreciation deductions) as a result of including the nonrecourse debt in his basis, the courts have assumed that things should just about even out if $T$ includes in his amount realized that nonrecourse mortgage which provided him the tax benefit in the first place. In support of this analysis, the courts have relied upon the Supreine Court's statement in Crane that "[t]he crux of this case, really, is whether the law permits [the taxpayer] to exclude allowable deductions from consideration in computing gain. We have already shown that, if it does, the taxpayer can enjoy a double deduction, $\mathrm{m}$ effect, on the same loss of assets." 38

Later courts have suggested that the only way to avoid this "double deduction" feared by the Crane Court is to require that the nonrecourse debt that was mcluded in the taxpayer's cost basis be included in his amount realized. ${ }^{39}$ Under this reasoning, the nonrecourse debt, which had given rise to depreciation deductions, would then not be excluded from consideration in computing gain. ${ }^{40}$

\section{The Actual Crane Holding}

The above analysis, though seemingly grounded in equitable notions, falls short of reaching them; and though seemingly grounded in the reasoning of Crane, it misperceives that case. The basic facts of Crane have been earlier discussed, ${ }^{41}$ but some expansion of the facts is necessary. Ms. Crane contended that the $\$ 250,000$ nonrecourse debt to which her property was subject was included in neither her original basis nor her amount realized. The Court first determined that Ms. Crane's origmal basis included the nonrecourse debt, and then determined that the debt was also included in her amount realized, because she was relieved of what she would have treated as her personal

37. Id.

38. 331 U.S. at 15 .

39. See infra text accompanying notes 96-99.

40. One problem with this analysis is that it provides no justification for inclusion of nonrecourse debt in a taxpayer's amount realized when a mortgage is placed on the property subsequent to purchase and is therefore not included in the taxpayer's adjusted basis. The result has been a pained and distorted analysis of such cases. See infra text accompanying notes 96-99.

41. See supra text accoinpanying notes 30-31. 
obligation. ${ }^{42}$

Ms. Crane also argued that, in any event, it was unconstitutional to include the debt in her amount realized because the result would be $\$ 27,500$ of ordinary income, and sle liad unade only $\$ 2,500$ total profit. ${ }^{43}$ Only at that point, in addressing the constitutional argument, did the Court mention the concept of "double deductions." It explained that the only reason Ms. Crane lad a gain on ler sale of the property was that her basis liad been reduced by adjustments for depreciation. Ms. Crane was economically enricleed by only $\$ 2,500$ from the transaction as whole; and in other circumstances, the Court had implied that a taxpayer could not realize incoine in excess of his actual economic benefit from the entire transaction. ${ }^{44}$ However, since Ms. Crane's gain included the recoupment of prior depreciation deductions, the amount of gam on disposition was not constitutionally limited to the taxpayer's actual economic enriclument from the transaction as a whole. Obviously, the $\$ 27,500$ gain on the disposition of property exceeded the taxpayer's overall net gain of $\$ 2,500$, but the tax consequences of the transaction as a whole accurately reflected the real net economic gain of $\$ 2,500$ ( $\$ 32,500$ gain on sale, less $\$ 30,000$ depreciation deductions). Had the prior deductions not been balanced by later income of $\$ 32,500$, Ms. Crane's real economic gain of $\$ 2,500$ would have been reflected for tax purposes as a net loss of $\$ 27,500$ ( $\$ 30,000$ of depreciation deductions less $\$ 2,500$ gam on sale). The Court decided only that Ms. Crane had no constitutional right to claim such a net loss. ${ }^{45}$

The Court's statement concerning double deductions was not relevant to its determination of Ms. Crane's amount realized, and it was not said to be a ground for that determination. It was noted only as a response to Ms. Crane's constitutional argument that she could have only $\$ 2,500$ of income on lier sale of the property. Therefore, to rely on the Court's discussion of double deductions to support an argument concerning inclusion of nonrecourse debt in amount realized is unjustified. The only stated reason for the Court's decision in Crane that the taxpayer's amount realized included the nonrecourse debt was the Court's judgment that, because the value of the property exceeded the debt, Ms. Crane would have treated the obligation as a personal one. ${ }^{46}$

42. 331 U.S. at 15.

43. 331 U.S. at $13,15$.

44. Bowers v. Kerbaugh-Empire Co., 271 U.S. 170, 175 (1926).

45. 331 U.S. at $15-16$.

46. The Fifth Circuit, in addressing the problem of "double deductions," stated that there had been no double deductions because the taxpayer had reduced his adjusted basis in the property by the amount of depreciation deductions allowed. The court misperceived both the problem of "double deductions" and the effect of the basis adjustments required by I.R.C. $\$ 1016$ (Supp. V 1981). Ms. Crane had been allowed $\$ 25,000$ of depreciation on her property. She deducted this 


\section{The Results: Excessive Capital Gains}

Perhaps stretching the language of Crane would be justified if the result was consistent with basic tax policy. It is not. In Crane, the taxpayer had taken depreciation deductions that had offset approximately $\$ 25,000$ of ordinary income. When she disposed of the property, her taxable income was increased by that same $\$ 25,000$ of ordinary income. ${ }^{47}$ While Ms. Crane received some tax advantage by being able to take her deductions long before she had to include the saine ainount in income, at least the amount she included in taxable income upon disposition was the same amount she had deducted in depreciation. The approach of the Tax Court, the Second Circuit, the Third Circuit, and those who have commented on Tufts to date would not achieve this balance.

To return to our hypothetical, in the five years that $T$ has held the property prior to disposition, $T$ has reduced his taxable incoine by the $\$ 100,000$ of depreciation he has deducted. Of this, $\$ 20,000$ represents his actual cash outlay for the property. To balance the $\$ 80,000$ of additional income that was offset by T's depreciation deductions, his taxable income would have to be increased by $\$ 80,000$ on his disposition of the property. ${ }^{48}$ Under the above view, it is not. T's amount realized,

amount only one time, so the Court's use of the term "double deductions" was a somewhat inappropriate description of the problem it saw. The problem in Crane was that Ms. Crane had deducted an amonnt $(\$ 25,000$ of deprcciation) that she had never paid. The Conrt appears to have concluded that since the deducted anounts were never actually paid, the taxpayer had no right to ignore the tax benefit she had derived from those dedcutions in determining her gain on the sale of the property.

The Fifth Circuit was correct in its nnstated assumption that generally the adjustments to basis required by section 1016 will increase the taxpayer's gain on sale. Since gain is equal to the spread between the taxpayer's amount realized and his basis, a decrease in basis generally increases the spread between the amount realized and the basis, and increases the gain on the sale. The correctness of that assumption, however, does not address the "double deduction" problem in the rufts case or in our hypothetical. The reduction of basis does not produce any current tax consequences. It accounts for the allowed but unpaid deductions only if it increases the spread between the taxpayer's amount realized and the property's adjusted basis at the time of sale. If the taxpayer deducts an anount that is never paid ( $\$ 25,000$ in Crane; $\$ 80,000$ in our hypothetical) then that amount should be returned to the treasury in the form of income equal to the unpaid deduction. Reduction of basis does not achieve that result where the taxpayer's annount realized is less than his basis as reduced.

Although incorrcet in its perceived solution to the problem of "donble deductions," the Fifth Circuit in Tufts was correct in its assertion that the problem does not require inclusion of the full nonrecourse debt in the taxpayer's amount realized. As will be shown in this Part and in Part III, the "double deduction" problem should not arise in $T u f t s$ or in our hypothetical because the deductions taken but not paid may be included in the taxpayer's gain by methods more appropri-" ate than inerely increasing his amount realized.

47. Ms. Crane's property was not a capital asset, so she was not entitled to the deduction for long term capital gains. 331 U.S. at 5 n.9.

48. Actually, T's depreciation dednctions were mcreased by $\$ 95,000$ (25\% of $\$ 380,000)$, not merely $\$ 80,000$, as a result of his mclusion of the nonrecourse debt in his basis. See infra text accompanying note 63 . 
including the full nonrecourse debt, would be $\$ 380,000$. His original basis was $\$ 400,000$, and is by now only $\$ 300,000$ (the result of adjustments for the $\$ 100,000$ of depreciation). His gain on the disposition is thus $\$ 80,000$ (the excess of his $\$ 380,000$ anount realized over his adjusted basis of $\$ 300,000$ ). Because this gain, unlike the gain in Crane, is long term capital gain, only $40 \%$ of the gain in T's case will be included in his taxable income. ${ }^{49}$ Thus, of the $\$ 80,000$ of ordinary income offset by depreciation, only $\$ 32,000$ is ever returned to T's taxable income; the rest, through the deduction for long term capital gains, is never recovered by the Treasury.

\section{Justification for Capital Gains Treatment}

Of course, the mere fact that a taxpayer's income on disposition is not increased to the same extent that his income has been decreased through depreciation deductions does not indicate that the result is incorrect or even inequitable. The deduction for long term capital gains has long been a part of our tax system, and the fact that it inay benefit certain taxpayers is no cause to disapprove of its application. It is instructive, however, to see whether the disposition of property that has declined in value but is subject to a nonrecourse mortgage is the type of transaction to whicl the capital gains rules were ineant to apply. If not, it seems inappropriate to invent an outcoine, such as that described above, that has little basis in logic, solely in order to characterize the disposition as one resulting in substantial capital gains.

\section{a. Appreciation in Value Over a Substantial Period of Time}

As the Supreme Court stated more than 20 years ago, one justification for the capital gains provisions is to provide a means of easing the tax consequences on transactions that resulted in "the realization [in a single year] of appreciation in value over a substantial period of time." "To This justification, lowever, is not applicable to Tufts or to our hypothetical. In our hypothetical, when $T$ buys property for $\$ 400,000$ and the property is worth $\$ 200,000$ at disposition, there has obviously been no "appreciation in value" of the property over any period of time. $T$ has made a bad investinent (at least aside froin the tax benefits le has realized). By buying property for $\$ 400,000$ and disposing of the property when it is worth $\$ 200,000$, T lias clearly realized no gain from appreciation of the property. If anything, lie lias realized a capital loss, because he is disposing of property that lias suffered a decline in value greater than that reflected by the allowable depreciation.

49. I.R.C. \& 1202(a) (Supp. IV 1980).

50. Commissioner v. Gillette Motor Transp., Inc., 364 U.S. 130, 134 (1960). 


\section{b. Lock-In Effect}

Another common justification for special treatment of capital gains is that full taxation of capital gains would tend to "lock-in" capital. $^{51}$ In other words, a taxpayer whose investment has substantially appreciated may at soine time find a preferable alternative investment. If this occurs, not only the investor, but also the economy on the whole will benefit if the investor's assets are invested in the superior investinent. The investor will earn more on his investınent, and the econoiny will be strongest when funds are free to move into the inost promising enterprises. However, if an investor can avoid taxation by retaining his substantially appreciated investments, and if he will be fully taxed when he disposes of these appreciated (but now presumably stagnant) investments, he may be induced to leave his assets in the stagnant but nontaxed investment.

This justification for capital gains treatment has, of course, no apphication to the taxpayer in a situation such as the ones in Tufts or in our hypothetical. First of all, since the taxpayer's property is financed primarily by nonrecourse debt rather than cash, he does not have his capital invested, and the taxpayer's reconveyance will do nothing other than place the property in the hands of the real imvestor. Second, the taxpayer's return of the property is in any event not governed by his determination of the relative appeal of different investments. His disposition is a result of the fact that he is unwilling to pay the amount of the nonrecourse debt ( $\$ 380,000$ in our hypothetical) in order to keep property worth much less (i.e., $\$ 200,000$ ). In effect, the taxpayer is locked out by his bad investment, but is not locked in by adverse tax consequences.

There inay be situations where a taxpayer has made a substantial down payment for the property and also takes subject to a nonrecourse debt for the balance of the purchase price. If the property declines in value below the outstanding inortgage, the taxpayer may be deterred from disposing of his property by the knowledge that the disposition may result in substantial tax hability. ${ }^{52}$ Arguably, then, the taxpayer could be "locked into" his investment, and capital gains treatment could be a way to unlock those funds. However, this is not the kind of "lock-in" effect to which the capital gains provisions are directed.

51. See Brown, The Locked-in Problem, in Federal TAX PoLICY for Economic Growth AND STABILITY 367 (1955).

52. For example, if a taxpayer has property with an adjusted basis of $\$ 40$, worth $\$ 90$, and subject to a nonrecourse note of $\$ 100$, payment of the $\$ 100$ debt to maintain the property worth only $\$ 90$ would result in an economic loss of $\$ 10$. Forfeiture, however, would result in a taxable gain of $\$ 50$ ( $\$ 100$ nonrecourse debt less $\$ 50$ adjusted basis). The tax on this $\$ 50$ would exceed the $\$ 10$ loss the taxpayer would suffer by paying off the mortgage. 
The deduction for capital gains is intended to enable taxpayers to keep their assets in the inost productive investinents. The taxpayer whose property is declining in value is generally encouraged to divest himself of that asset and to invest in more productive property before its value declines substantially. To provide a bonus in the form of the deduction for capital gains to a taxpayer whose property declines in value below the nonrecourse debt would be to reward taxpayers who retain unproductive investments, especially in light of the other substantial tax benefits the taxpayer may be receiving by retaining his declining investment. To let taxpayers know that they will not receive favorable tax treatment by retaining their economically unsound investments will encourage taxpayers to dispose of those unprofitable investments before they so decline in value, thus encouraging taxpayers to invest in economically viable enterprises.

Indeed, while capital gains are given favorable tax treatment by the Code, capital losses are treated worse than any other kinds of losses. Rather than giving a tax preference to the taxpayer who holds onto his unprofitable investment, the Code severely limits the tax value of his loss by allowing it to offset only capital gains rather than ordinary imcome $^{53}$ The taxpayer whose unprofitable investment happens to secure nonrecourse debt has no reason to be treated any more favorably. The inclusion of that nonrecourse debt in the taxpayer's amount realized would improperly grant favorable treatment by allowing him to take advantage of the deduction for long term capital gams even though he has actually made an unprofitable investment.

\section{Gains Through Inflation}

The other principal justification for the favorable treatment accorded capital gains mvolves the fact that an increase in price of an investor's assets is often a result not of any real gain, but of mflation. ${ }^{54}$ Since the sale of an asset may result im taxable gain even though the increase in price inerely represents inflation, the gain on the sale, if taxed at all, should at least be given a gentler treatinent than that given "real" incoine. If, as in Tufts and in our hypothetical, the taxpayer's mortgaged asset has declined in value and his gain, if any, on disposition is a result of his inethod of financing rather than inflation, this justification for capital gains treatınent is also inapplicable to his situation.

Since the transaction at hand is not the kind of transaction to which the capital gains provisions are aimed, and since it does not

53. I.R.C. $\S \S 165(f), 1211,1212$ (1976 \& Supp. IV 1980).

54. 1 B. BITTKER, FEDERAL TAXATION OF INCOME, Estates AND GifTS $\$ 3.5 .7$ n.39 (1981). 
merit favorable tax treatment for any other identifiable reason, the invention of a legal justification for giving capital gains treatment to the taxpayer on his disposition of the mortgaged property is unwarranted.

\section{B. The Appropriate Application of the Tax Benefit Rule}

This Section examines the tax benefit rule in its current form and apphes it to our hypothetical. The simplest form of the tax benefit rule falls far short of balancing the tax benefits the taxpayer has enjoyed through depreciation with his tax burden on disposition of the inortgaged property. A more sophisticated approach comes closer to achieving that balance, but still falls short. An expanded version of the tax benefit rule is presented that accounts for prior tax benefits in a more complete fashion than any approach suggested to date.

\section{How the Rule Works}

The often suggested inclusion of nonrecourse debt in a taxpayer's amount realized on disposition of the property has, as noted, aspects of a tax benefit or economic benefit argument-the debt was included in the taxpayer's depreciable basis, so it should be included in his annount realized. While the tax law does recognize a tax benefit rule, a proper apphication of the rule would not result in an increase in T's amount realized. The basic tax benefit rule holds that if the payment (or accrual) of an expense results in a deduction, and if the amount paid is returned (or if previously accrued, not paid), the return (or failure to pay) results in gross income. ${ }^{55}$ In other words, a taxpayer whose liability to make a given payment is fixed may accrue that anticipated payment as a deduction. If, for some reason, that payment is not made, the amount previously taken out of taxable income by way of deduction must be returned by bemg included in gross income when it becomes apparent that the payment will not be made.

55. See generally Bittker \& Kanner, The Tax Benefit Rule, 26 U.C.L.A. L. REv. 265 (1978); Plumb, The Tax Benefit Rule Today, 57 HaRv. L. Rev. 129 (1943); Note, The Tax Benefit Rule, Claim of Right Restorations, and Annual Accounting: A Cure for the Inconsistencies, 21 VAND. L. REv, 995 (1968).

The rule has been applied to numerous kinds of expenses that have been deducted and then later returned. Among the most common are: (1) bad debts that have been written off and then later collected, National Bank of Commerce of Seattle v. Commisioner, 115 F.2d 875, 877 (9th Cir. 1940); (2) state taxes that have been paid and deducted, but which are later refunded, I.R.C $\$ 111$ (1976 \& Supp. IV 1980); (3) casualty losses that have been deducted and then later compensated for by insurance or otherwise, Rev. Rul. 71-160, 1971-1 C.B. 75; and (4) deductions taken upon the issuance of checks for deductible wages or supplies when the checks are never cashed, Roxy Custom Clothes Corp. v. United States, 171 F. Supp. 851, 854 (Ct. Cl. 1959). The tax benefit rule also mandates the exclusion from income of unpaid, or returned, items of deduction if the deduction did not decrease the taxpayer's acutal tax hability. For purposes of this Article, only the rule of mclusion, explained in the text accompanymg this note, is relevant. 


\section{The Rule Applied in its Simple Form}

The tax benefit rule in its simple form is directly applicable to our hypothetical fact pattern. When a taxpayer pays $\$ 20,000$ cash for property subject to a $\$ 380,000$ nonrecourse mortgage, his basis includes the nonrecourse debt only if that debt approximates the property's fair market value, and only because it appears at the time of purchase that he will actually pay off that debt. ${ }^{56}$ Thus, the taxpayer's cost basis includes not only the $\$ 20,000$ he has paid, but also the $\$ 380,000$ he will pay. If the taxpayer acquires a long-lived asset, he cannot currently deduct the cost of that asset, but he must capitalize that cost. ${ }^{57}$ When he takes depreciation from his cost basis (here, $\$ 400,000$ ), he is simply accounting in statutorily specified periods for both the $\$ 20,000$ that lie has already paid out and for the $\$ 380,000$ that he will pay. While his deductions take the form of an allowance for depreciation, the Supreme Court has made clear its view that "[t]here is no question that the cost of . . . [depreciable property is] 'paid out' in the same manner as the cost of supplies, materials, . . . and . . . wages." 58

The rules requiring capitalization and depreciation, as opposed to immediate expensing, of capital outlays do not change the fact that what $\mathrm{T}$ in our liypothetical is deducting is the $\$ 20,000$ he lias paid and the $\$ 380,000$ he will pay; these rules merely govern timing-when can he deduct these past and future payments. Thus, while depreciation rules require accounting for payments in years other than when made, depreciation inerely governs the timing of the deduction for otlierwise deductible amounts paid out by the taxpayer.

A taxpayer using the accrual inethod of accounting may deduct expenses prior to actual payenent if his liability is fixed and the amount of his liability is determinable with reasonable accuracy. ${ }^{59}$ Similarly, a taxpayer who has purchased property subject to a nonrecourse debt uses the method of accounting specified by sections 167 or $168^{60}$ to deduct amounts prior to his actual payinent thereof. The deduction for depreciation thus does not necessarily reflect the decline in an asset's value. ${ }^{61}$ It is inerely a method of accounting that governs the time that either past or future payments can be deducted.

56. Crane, 331 U.S. at 5-11; Mayerson, 47 T.C. 340, 351-52 (1966); Rev. Rul. 69-77, 1969-1 C.B. 59.

57. I.R.C. \& 263 (1976 \& Supp. IV 1980).

58. Commissioner v. Idaho Power Co., 418 U.S. 1, 16 (1974).

59. Treas. Reg. § 1.461-1 (1967).

60. I.R.C. $\$ \$ 167,168$ (West 1978 \& Supp. 1982) provide the allowable methods of accounting for capital cost recovery.

61. This statement is especially true in light of I.R.C. $\$ 168$ (Supp. V 1981), which makes no attempt to inatch capital cost recovery with either an asset's decline in value or the asset's expected useful life. 
If our taxpayer, with a cost basis of $\$ 400,000$, has taken $\$ 100,000$ of depreciation deductions in the five years he has held property, he has done nothing more than deduct the $\$ 20,000$ cash down payment he made and $\$ 80,000$ of the $\$ 380,000$ nonrecourse debt that he intends to pay in the future. An appealing conclusion to this tax benefit analysis is that when he disposes of the property without paying any of the $\$ 380,000$ nonrecourse debt, $\$ 80,000$ of which he has already deducted, the deducted and unpaid amount must be included in the taxpayer's gross income. Unfortunately, the analysis is not quite so simple.

When the taxpayer disposes of his mortgaged property worth $\$ 200,000$ by transferring the property back to the mortgagee, he does so im satisfaction of his nonrecourse debt. This debt, as has been shown above at pages 93-95, is an amount equal to the lesser of the fair market value of the property or the face amount of the debt. To satisfy his debt, he has transferred property worth $\$ 200,000$. In essence, then, for the property that the taxpayer temporarily possessed, he has paid $\$ 20,000$ cash plus property worth $\$ 200,000$, for a total of $\$ 220,000$.

In its simplest form, the tax benefit rule would seem to lead to the conclusion that through the allowance for depreciation, the taxpayer has deducted a total of $\$ 100,000$, representing his $\$ 20,000$ cash payinent and $\$ 80,000$ of additional payments he thought he would make. Had $T$ in fact paid less than $\$ 100,000$, he would have then recieved a tax benefit of $\$ 100,000$ of deductions and would be required to return that tax benefit as income only to the extent it represented amounts not actually paid. Only if the sum of the taxpayer's payinents-his cash payinent plus the value of the property at the time of disposition-were less than the sum of his depreciation deductions would he have actually deducted, as depreciation, amounts that he did not pay, and only then would the tax benefit rule apply to give him income.

So far, then, $\mathrm{T}$ would appear to have no ordinary income under the tax benefit rule, and only a long term capital loss of $\$ 100,000$ (excess of adjusted basis of $\$ 300,000$ over ainount realized of $\$ 200,000$ ) when he disposes of the property. If and when $T$ deducts his long term capital loss of $\$ 100,000$, however, that deduction is a separate tax benefit, achieved only through the inclusion in T's basis of the remaining $\$ 300,000$ of nonrecourse debt. Since that deduction represents an amount (the $\$ 100,000$ excess of his adjusted basis over his amount realized) that will never be paid, $T$ would be required to include in income a corresponding amount under tax benefit principles. Generally, in determining the character of income accrued as the result of the tax benefit doctrime, courts have applied the principle of Arrowsmith $v$. 
Commissioner: ${ }^{62}$ when the gain is a result of the balancing out of a prior transaction, the character of the gain should reflect the character of that prior transaction. Thus, where the tax benefit rule generates $\$ 100,000$ of incoune to counter a $\$ 100,000$ capital loss, the $\$ 100,000$ income will also be capital in character, netting out the transaction to produce no net gain or loss on T's return of the property.

On the whole, the simple form of the tax benefit rule still falls far short of actually balancing out the tax benefits that the taxpayer enjoyed prior to disposing of the property. Instead, the taxpayer who has deducted $\$ 100,000$ of depreciation while holding the property, and whose total out-of-pocket cost has been $\$ 20,000$, has deducted $\$ 80,000$ inore than he has actually lost. The simple form of the tax benefit rule fails to account for those excessive deductions.

\section{A More Sophisticated Approach}

The simple form of the tax benefit rule seeins to leave $T$ substantially better off than he would be were the unpaid nonrecourse debt included in T's anount realized. The rule prevents the deduction of a capital loss, but it does not appear to generate any incoine of any character. A more sophisticated analysis of the apphication of the tax benefit rule to T's situation, focusing inore on what T's depreciation deductions actually represent, reveals that, in fact, the rule results in a less favorable treatinent of $T$ than the simple analysis would indicate.

The rules requiring capitalization and depreciation of assets with useful hives of more than a year are merely timing mechanisins. They govern when ainounts paid or to be paid can be deducted. If T's property has a useful life of 20 years and no salvage value, then, using straight line depreciation, $T$ can deduct $1 / 20$ of his cost in each year. For each dollar that $T$ has paid or will pay, he can deduct $1 / 20$ (five cents) in each of the 20 years the property can be expected to last. After one year, he has deducted five cents of each dollar; after five years he has deducted 25 cents of each dollar. If $\mathrm{T}$ has property with a cost basis of $\$ 400,000$ and he takes $\$ 100,000$ of depreciation during his first five years of ownership, he has then deducted 25 cents of each of the $\$ 400,000$ of his cost. If $T$ has paid $\$ 20,000$ cash, then he has deducted $25 \%$ of that cash payment; and if $\mathrm{T}$ has taken the property subject to the $\$ 380,000$ of nonrecourse debt that was included in his basis, he has, after five years, also deducted $25 \%$ of each dollar of that debt.

When T returns his property, then worth $\$ 200,000$, to the original seller, T pays $\$ 200,000$ of the $\$ 380,000$ that had been included in his basis. Thus, $\$ 180,000$ of the $\$ 380,000$ debt was never paid. Since. $25 \%$

62. 344 U.S. 6, 8 (1952). See also Bittker \& Kanner, supra note 55, at 276. 
of that $\$ 180,000$ that went unpaid has already been deducted in the form of depreciation, that amount must be included as ordinary income when it becomes clear that the deducted amount will not be paid. Thus, on disposing of the property, $\mathrm{T}$ has $\$ 45,000$ of ordinary income ${ }^{63}$ under the tax benefit rule, and this $\$ 45,000$ of income represents that part of the nonrecourse debt that was deducted and never paid. ${ }^{64}$ While this approach is preferable to the simple application of the tax benefit rule, it is still not sufficient.

\section{Expanded Application of the Rule \\ a. How It Should Work}

The tax benefit rule is applied to increase a taxpayer's income when the taxpayer recoups an amount that had previously resulted in a decrease in imcome. In most of the decided cases, this decrease in taxable income has been the result of the taxpayer having deducted anounts that he ends up not paying or that, having been paid, are later refunded. ${ }^{65}$ The fact that unpaid amounts may not have been deducted, however, does not mean that the unpaid amounts produce no tax benefit. As im our hypothetical, an amount may produce a real reduction in income by domg just that-reducing gross income-rather than merely providimg a deduction from that income. Had $\mathrm{T}$ not increased his basis by the $\$ 180,000$ of nonrecourse debt that ends up unpaid at the time of disposition, he would have property with an adjusted basis of only $\$ 120,000$ ( $\$ 220,000$ actually paid less $\$ 100,000$ adjustments for depreciation). Simce his amount realized is $\$ 200,000$, he would have $\$ 80,000$ of gam upon his disposition of the property.

63. Although the tax benefit rule ought to produce income equal to and corresponding in character to the taxpayer's unpaid deductions, some inay argue that the application of the rule to produce ordinary income in T's situation defeats the purpose of a separate statutory provision intended to govern the characterization of gain on the sale or exchange of depreciable real property. I.R.C. $\$ 1250$ (West 1967 \& Supp. 1982) generally provides that when depreciable real property is sold or exchanged, the gain that represents depreciation in excess of that allowed by the straight-line method is to be characterized as ordinary income. That section, however, does not limit the application of the tax benefit rule to T's situation. Section 1250 recharacterizes as ordinary income a certain anount of what would otherwise be capital gain. As noted, $T$ has no capital gain when he disposes of his property (other than that generated by the tax benefit rule to counter his $\$ 100,000$ capital loss on the exchange). His incoine is not gain from the sale or excliange of an asset. It is income produced under the tax benefit rule-not the kind of income to which $\S 1250$ has any relevance.

Additionally, section 1250's purpose is to insure that some part of the gain that would otherwise be capital is treated as ordinary income. The section was not intended to limit the amount of ordinary incoune, but ouly to generate ordinary income in the absence of any other rule that might do so.

64. Although T's amount realized is only $\$ 200,000$, as explained supra text accompanying note 62 , the tax benefit rule would also prevent $T$ froin deducting a long term eapital loss to offset any of his $\$ 45,000$ of ordinary imcome.

65. See generally Bittker \& Kanner, supra note 55; Plumb, supra note 55. 
Thus, a very real tax benefit produced by T's inclusion of the unpaid $\$ 180,000$ in his basis is the exclusion of that $\$ 80,000$ of gain from his incoine on his disposition of the property.

When a tax benefit is produced by a reduction in gross incorne resulting froin the inclusion of the unpaid purchase price in a taxpayer's adjusted basis, that benefit is no less real than the benefit produced by the reduction of incoine through the allowance of a deduction. The theory behind the tax benefit concept would support the extension of that concept to include in income unpaid or refunded amounts that have reduced taxable incoine by increasing the basis of property; and since the tax benefit concept is of judicial origin, the Court would not be constrained by statutory language from appropriately expanding that concept. ${ }^{66}$

In fact, the tax benefit rule has been einployed in other situations where the prior benefit did not take the form of a deduction, but took the form of an exclusion of amounts from gross income. In Keystone National Bank v. United States ${ }^{67}$ the taxpayer had been the victim of embezzleinent. Amounts that would have been included in imcoine were excluded because they were embezzled prior to reaching the taxpayer. Even though amounts had not been deducted and later refunded, the taxpayer had enjoyed a tax benefit by excluding the embezzled amounts froin his incoine. When these ainounts were later received, they were held to constitute income under the tax benefit rule. ${ }^{68}$

In our hypothetical, $\mathrm{T}$ has likewise enjoyed a tax benefit by excluding amounts from imcoine. Had $T$ not imcluded the full unpaid debt in his basis, aside from being allowed less depreciation, $T$ would have recognized $\$ 80,000$ of gain on his disposition of the mortgaged property. The exclusion of this gain from T's income is as clear a tax benefit as was the exclusion of the embezzled funds from the income of Keystone. In Keystone, the einbezzled funds were included in incoine when they were finally received. While $\mathrm{T}$ does not actually receive funds, he is relieved of any obligation to repay ainounts he had owed. This benefit is just as real and substantial as if he had received funds, ${ }^{69}$ and when the benefit is realized, the tax benefit rule should coine into play. ${ }^{70}$

66. Cf. B.C. Cook \& Sons, Inc. v. Commissioner, 584 F.2d 53 (5th Cir. 1978) (court felt bound by language of I.R.C. $\S 1312(2)$ (1954) to reach admittedly inequitable result).

67. 52 A.F.T.R. (P-H) 1511 (W.D. Pa. 1957).

68. Id. at 1512. See also Alsop v. Commissioner, 290 F.2d 726 (2d Cir. 1961); Union Trust Co. v. United States, 173 F.2d 54, 56 (7th Cir.), cert. denied, 337 U.S. 940 (1949).

69. Diedrich v. Commissioner, 102 S. Ct. 2414, 2418-19 (1982).

70. See, e.g., Tennessee-Carolina Transp. Inc. v. Commissioner, 582 F.2d 378, 382 (6th Cir. 


\section{b. Character of the Gain}

If the tax benefit rule is construed to give $T$ gain on his disposition equal to the real benefit he has received from inclusion of the $\$ 180,000$ in his basis, he will have $\$ 80,000$ of gain when he disposes of the property. This would simply be the gain he would have had had his original cost basis included only his actual payments of $\$ 220,000$. The gain would be the excess of his $\$ 200,000$ amount realized over an adjusted basis of $\$ 120,000$ (cost basis of $\$ 220,000$ less $\$ 100,000$ adjustinents for depreciation). The next question, then, is: What is the character of this $\$ 80,000$ gain? Although the entire $\$ 80,000$ of gain is realized ouly because $\mathrm{T}$ took depreciation deductions that reduced his basis, and although these depreciation deductions offset T's ordinary incoine, not all of his gain on disposition will be ordmary income under the tax benefit rule. Instead, $T$ will have $\$ 45,000$ of ordinary income and $\$ 35,000$ of long term capital gain.

Of the unpaid $\$ 180,000, \$ 45,000(25 \%)$ has been deducted in the form of depreciation. As noted, under established tax benefit principles, this previously deducted a1nount results in ordinary incoine when it goes unpaid. ${ }^{71}$ The remaining $\$ 135,000$ of unpaid cost was never deducted. Instead, it produced a tax benefit only by increasing T's basis and excluding a portion of his amount realized from his gain. Had T's adjusted basis on disposition not included this unpaid $\$ 135,000$, the basis would have been $\$ 165,000$ (original basis of $\$ 400,000$ less $\$ 100,000$ adjustments for depreciation, less $\$ 135,000$ unpaid ainounts). Since his amount realized is $\$ 100,000, T$ would have a capital gain of $\$ 35,000$ on his disposition of the property. When it becoines clear that this $\$ 135,000$ will not be paid, the tax benefit enjoyed as a result of inclusion of that amount in basis (tliat is, the exclusion of $\$ 35,000$ of gam) must be taken back into income. Thus, T's total incoine includes $\$ 35,000$ of capital gam as well as $\$ 45,000$ of ordinary income.

\section{Residential Real Property: Section 1250 Characterization of the Gain}

This same characterization of gain can be achieved by approaching the transaction from a different perspective. T's adjusted basis, not includimg the unpaid $\$ 180,000$, is $\$ 120,000$ at the time of disposition. Tax benefit concepts aside, the difference between that basis and his $\$ 200,000$ amount realized would produce long terin capital gain, subject to recharacterization by Internal Revenue Code section 1250. That

1978) for the proposition that "[t]he tax benefit rule should be applied flexibly in order to counteract the inflexibility of the annual accounting concept ...."

71. See supra notes $63-64$ and accompanying text. 
section is intended to recharacterize, as ordinary incoine, gam from the sale or exchange of depreciable residential real property only to the extent that the gain is the result of depreciation having been taken on that property in excess of that which would have been allowed under the straight-line inethod.

In the legislative history of section 1250 , Congress nade clear its belief that a price increase due to a general rise in price levels of real property represents the kind of gradual appreciation in value to which the capital gains provisions were intended to apply. It made equally clear its belief that gain on sale that was the result not of increase in value of real property over time, but of excessive depreciation deductions (that is, deductions that (1) exceeded the actual decline in value of the property due to wear and tear and obsolescence, and (2) resulted in adjustments that lowered a taxpayer's adjusted basis and resulted in additional gain on sale) should not be entitled to capital gains treatinent. ${ }^{72}$ Instead, under a tax benefit concept, Congress believed that such gain should be of the saine character as were the original depreciation deductions. ${ }^{73}$

Unable to determine, in any particular case, what part of gain on sale represented a general price rise and what part was the result of excessive depreciation, Congress coinpromised. It decided to assume that, for purposes of section 1250, real property would in all cases suffer wear and tear equal to that represented by straight-line depreciation, so if a taxpayer takes only straight-line depreciation on his real property, any gain realized on a later sale is assuined to represent a general rise in prices rather than excessive depreciation. To the extent a taxpayer is allowed to deduet depreciation in excess of straight-line depreciation, however, gain on a later sale is assuined to represent this excess depreciation rather than a general price rise, and the excess depreciation is recaptured as ordinary incoine.

To return to our liypothetical, T's actual payinents for the property totaled $\$ 220,000$. If $T$ had taken an original cost basis of $\$ 220,000$, allowable straight-line depreciation over five years would have been $\$ 55,000$. T's basis would have been adjusted to reflect this depreciation, so that his adjusted basis would be $\$ 165,000$ at the time of disposition ( $\$ 220,000$ less $\$ 55,000$ ). If $T$ realized $\$ 200,000$ on his disposition of the property, he would have $\$ 35,000$ of gain (excess of $\$ 200,000$ amount realized over adjusted basis of $\$ 165,000$ ). Since $T$ would have taken the allowable straight-line depreciation $(\$ 55,000)$, none of the gain would be recaptured by section 1250 . In our lypothetical, however, $T$ has taken a cost basis not of the $\$ 220,000$ he actually paid, but

72. S. Rep. No. 830, 88th Cong., 2d Sess. 133 (1964) [hereinafter cited as S. REP. No. 830].

73. $I d$. 
of $\$ 400,000$. He has deducted not $\$ 55,000$ of depreciation, but $\$ 100,000-\$ 45,000$ more than would have been allowable under the above use of the straight-line method.

If the unpaid $\$ 180,000$ of debt were excluded from T's adjusted basis, his adjusted basis would become $\$ 120,000$ ( $\$ 220,000$ payments less $\$ 100,000$ adjustments for depreciation). When $\mathrm{T}$ has an amount realized of $\$ 200,000$ on his disposition, he would have a total gain of $\$ 80,000$, rather than $\$ 35,000$. The extra $\$ 45,000$ of his gain is the result of the excess depreciation. It would seem, under Congress' intentions, to warrant characterization as ordinary income.

The language of section 1250 does not make clear whether it would im fact apply to T's case in this manner. The section requires the recapture, as ordinary income, of depreciation deductions "to the extent that they exceed the amount of the depreciation adjustinents which would have resulted if such adjustments had been determined for each taxable year under the straight-line method of adjustment." ${ }^{14}$ The problem in T's case, that section 1250 understandably does not address, is that his depreciation deductions were determined under the straightline method. His depreciation adjustments exceed those that would have resulted from application of the straight-line method to what his original cost basis should have been $(\$ 220,000)$, but they do not exceed those that would result from the application of the straight-line method to his original, and incorrect, cost basis of $\$ 400,000$. Section 1250 does not specify what basis is to be used for determining the "adjustments which would have resulted .. . under the straight-line method."75 The choice is between using (1) T's actual payments of $\$ 220,000$ as his cost basis, or (2) T's original, and incorrect basis of $\$ 400,000$. Given a choice of using the correct basis or an incorrect basis, the choice seems clear. ${ }^{76}$ When the correct basis of the $\$ 220,000$ actually paid is used to determine the proper straight-line depreciation, the result is as just described: $\$ 45,000$ of ordinary income and $\$ 35,000$ of capital gam.

\section{d. The Mechanics of the Expanded Tax Benefit Rule and Section 1250}

The expanded use of the tax benefit rule in the case of depreciable residential property, then, would result in more ordinary income in the Tufts setting than would inclusion of the full amount of the nonre-

74. I.R.C. $\S 1250(a)(1)-(b)(1)$ (1976 \& Supp. IV 1980).

75. I.R.C. $\S 1250$ (b)(1) (1976).

76. Since the tax benefit rule has yet to be properly applied to our hypothetical, no court has yet ruled on how section 1250 would apply to the disposition of property whose basis has been reduced because of tax benefit principles. For discussion of a somewhat analogous problem, see infra text accompanying notes 130-33. 
course debt in the taxpayer's amount realized. As shown, the rule requires a two-pronged analysis. First, the taxpayer must determine what percentage of his original cost basis has already been deducted (in our hypothetical, it was $25 \%$ ). He must then determine what amount of that basis has gone unpaid (here $\$ 200,000$ cash plus $\$ 200,000$ worth of property was paid; $\$ 180,000$ of the origmal $\$ 400,000$ cost basis remained unpaid). To the extent unpaid amounts have been deducted (i.e., $25 \%$ of $\$ 180,000$ ), they must be included in ordinary income.

Next the taxpayer inust compute the unpaid amounts that were mcluded in his cost basis, but which have not been deducted (for $\mathrm{T}$, $\$ 135,000$ : $\$ 180,000$ total unpaid amount less $\$ 45,000$ deducted and accounted for im step one). These amounts benefit the taxpayer by increasing his basis. The taxpayer must therefore balance out that benefit, under the tax benefit rule, by reducing his basis upon disposition by an amount equal to these unpaid and as yet unaccounted for amounts that were included in basis $(\$ 135,000)$. The taxpayer would then realize a gain (presumably capital) equal to the excess of the amount realized $(\$ 200,000)$ over the adjusted basis $(\$ 400,000-\$ 135,000$ $\$ 100,000=\$ 165,000$ ), which, in our hypothetical, is $\$ 35,000$.

The same result may be reached by eliminating from the taxpayer's basis any anounts previously included therein but never paid. If this is done, section 1250 recaptures, as ordinary income, any depreciation im excess of what would have been allowed had the straight-line method been applied to a cost basis that mcluded only the announts actually paid by the taxpayer. This recapture will result in ordinary mcome equal to the deducted but unpaid purchase price determined above. The remaining gam on disposition of the property will be long term capital gam. ${ }^{77}$

The above approach may appear complex. However, the idea that equity should give way to simplicity has not been, and hopefully will not become, one of the principles of our income tax systein.

\section{e. Nonresidential Recovery Property: Section 1245}

While gam from the sale of the property at issue in Tufts was subject to characterization by section 1250 , much depreciable real property other than residential property placed in service after 1981 and all depreciable personal property is subject to the depreciation provisions of

77. If the property is $\S 1245$ property rather than $\$ 1250$ property, then, if the taxpayer has a gain on his disposition of that property, the gain will be ordinary incoune to the extent of any depreciation previously allowed. Whether the gain is the result of an increase in the taxpayer's amount realized or a decrease in his adjusted basis would not change the character of the income, as it does with $\S 1250$ property. See infro text accoinpanying notes $78-81$. 
section $1245^{78}$ rather than to section 1250 . Unlike section 1250 , section 1245 recaptures as ordinary incoine the gain on the sale of depreciable property to the extent that any depreciation had been taken at all, not just to the extent that excess depreciation had been taken. ${ }^{79}$

Had the taxpayer in our hypothetical possessed nonresidential real property placed in service after 1981 or depreciable personal property, and had he elected the accelerated depreciation now permitted by section $168,{ }^{80}$ section 1245 would characterize as ordinary income all his gain on the disposition of the property up to the full ainount of depreciation taken. Assuming that $T$ had taken a total of $\$ 100,000$ of accelerated depreciation (taking four years rather than five, because of the more rapid cost recovery permitted by section 168), he would still have $\$ 45,000$ of ordinary income under the tax benefit rule, as a result of having already deducted, by way of depreciation, that amount of unpaid purchase price. ${ }^{81} \mathrm{He}$ would have an additional $\$ 35,000$ of gain generated upon his disposition of the property by the effective reinoval from his basis of the remaining $\$ 135,000$ of unpaid purchase price ( $\$ 180,000$ unpaid less $\$ 45,000$ already accounted for). Since he would have taken more than $\$ 35,000$ of depreciation (in addition to the $\$ 45,000$ already accounted for), all of his $\$ 35,000$ gain would be characterized as ordinary income under section 1245. Thus, if the property in issue were governed by section 1245 , the expanded version of the tax benefit rule would produce $\$ 80,000$ of ordinary incoine upon disposition.

\section{III}

\section{INCOME From THE DisChARGE OF INDEBTEDNESS}

Generally, when a taxpayer has a debt that is discharged other than by paynent, the taxpayer whose debt is forgiven realizes ordinary income equal to the amount of debt cancelled. The taxpayer who

78. I.R.C. $\S 1245(a)(5)$ (West Supp. 1982).

79. Section 1245 , which recharacterizes gain on the sale of depreciable property other than most real property, converts gain into ordinary mcome to the extent that the gain represents previous depreciation deductions. If depreciation was deducted that did not represent actual decline in value of the property, the depreciation adjustments lower the property's basis and thereby increase the gain on the sale of the property. This increase in gain is ordinary incoine. In a sense, $\S 1245$ codifies the tax benefit rule-where depreciation has given rise to ordinary income to the extent it is a result of those deductions. Section 1250 was intended to serve a similar purpose with respect to real property. The difference between the two sections is the result of Congress' belief that, with repect to real property, gain on the sale inay be the result not only of depreciation deductions that were taken despite the lack of exhaustion or wear and tear on the property, but also of "an appreciable rise in the value of real property attributable to a rise in the general price level over a long period of time." S. REP. No. 830, supra note 72, at 132.

80. 1.R.C. \& 168 (West Supp. 1982).

81. See supra text accompanying notes $63-64$. 
purchases property subject to a nonrecourse mortgage is treated under Crane as having incurred a personal obligation. ${ }^{82}$ When he disposes of the property without paying the debt and with no obligation to pay it in the future, he has seen that quasi-personal debt discharged. Therefore, the result should be ordinary income in an amount equal to the unpaid debt.

\section{A. The General Rule: Recognition of Ordinary Income Upon the Discharge of Indebtedness}

A taxpayer does not realize income when he borrows inoney, ${ }^{83}$ presumably because while his assets may be teinporarily increased by the anount of the borrowing, he incurs a corresponding liability to return those borrowed funds im repayment of the debt. He thus has no economic gain when he merely borrows money. If, however, the taxpayer's personal obligation to return the borrowed funds to the lender is decreased or eliminated, he receives a rcal economic benefit equal to the amount by which his obligation is decreased. In general, if a taxpayer's obhigation is discharged by a third party, this economic benefit results in the realization of income. ${ }^{84}$ The Supreine Court in United States v. Kirby Lumber Co. ${ }^{85}$ held that if this discharge of the taxpayer's obligation takes the form of a cancellation or reduction of the amount he is required to repay to the lender, he has received a benefit that inust be included in his mcone. ${ }^{86}$ The mcoine so generated is treated as ordinary imcoine because it meets none of the criteria for treatınent as capital gains. ${ }^{87}$ The taxpayer who disposes of property without repaymg a substantial amount of the funds he borrowed to purchase that property ought to recognize just this kind of income.

\section{Application of the Rule to Nonrecourse Debt that Exceeds Fair Market Value}

The hypothetical with which we have been working can be used to illustrate the appropriate application of the rule of Kirby Lumber to the taxpayer who disposes of property subject to nonrecourse debt in excess of the property's value. As noted, the courts and the Service concedc that when $T$ pays $\$ 20,000$ cash for the property, he obtains $\$ 20,000$ of

82. Crane, 331 U.S. at 14; see supra text accompanying note 42.

83. Woodsam, $198 \mathrm{~F} .2 \mathrm{~d}$ at 359.

84. Old Colony Trust Co. v. Commissioner, 279 U.S. 716, 729 (1929).

85. 284 U.S. 1 (1931).

86. Id. at 3. See generally Bittker \& Thompson, Income from the Discharge of Indebtedness: The Progeny of United States v. Kirby Lumber Co., 66 CALIF. L. REv. 1159 (1978); Eustice, Cancellation of Indebtedness and the Federal Income Tax: A Problem of Creeping Confusion, 14 TAX. L. Rev. 225 (1959).

87. See I.R.C. \& 1222(3) (West 1967 \& Supp. 1982). 
equity in that property, for he will be able to retain the property, worth $\$ 400,000$, upon the payment of only $\$ 380,000$ of nonrecourse debt. ${ }^{88}$ $\mathrm{He}$ can be expected to treat that debt as his personal debt when it becomes due, because only by paying it can he protect his $\$ 20,000$ of equity in the property.

In T's case, as in Tufts, the initial behef that the property would retain its value was overoptimistic. Since T's property is worth $\$ 200,000$ at the end of 5 years, let us assume that its value has declined ratably over that period, so that it loses $\$ 40,000$ in value each year. At the end of year one, $T$ has property worth $\$ 360,000$, subject to nonrecourse debt of $\$ 380,000$. Since the debt is nonrecourse and since, lacking equity to protect, $\mathrm{T}$ is unlikely to treat the debt as a personal hability, T's sole obligation is to return the lesser of $\$ 380,000$ cash, or property he owns worth $\$ 360,000$. In other words, two things have happened to T: (1) his property has declined in value by $\$ 40,000$; and (2) T's debt has been reduced froin a quasi-personal obligation to pay $\$ 380,000$ cash, to an obligation to merely return property worth $\$ 360,000$.

As long as $\mathrm{T}$ is not treated as having disposed of his property, the decline in the property's value has no current tax consequences. ${ }^{89}$ The reduction of T's debt likewise appears to have no current tax consequences. T may be able to discharge his obligation for less than its face amount; but until he does so, that possibility is not realized and not taxed. Indeed, if it were, it inevitably wonld follow that alinost any debtor would have income when interest rates rise, because lie would then inost likely be able to satisfy his obligation immediately at a discount. ${ }^{90}$

By the end of his five year holding period, $T$ has seen his property decline in value to $\$ 200,000$. He has also watcled his obligation decline from $\$ 380,000$ to an obligation inerely to return property worth $\$ 200,000$. It is reasonable that T's bad investment will be treated as any other bad investment-the excess of T's adjusted basis in the property ( $\$ 300,000$, after adjusting for depreciation) over T's amount realized $(\$ 200,000)$ will be a long term capital loss upon T's disposition of the property. It is no less reasonable that the decrease in T's debt from $\$ 380,000$ to $\$ 200,000$ will be treated the same as other nondonative decreases in debt; when the debt is finally discharged, the debtor has ordi-

88. See supra text accompanying notes 30-33.

89. Eisner v. Macomber, 252 U.S. 189, 207 (1920).

90. For example, assume that a creditor has loaned $\$ 100,000$ at $10 \%$ interest, repayable in five years. If the interest rate rises to $20 \%$, he would gladly accept less than $\$ 100,000$ now in order to be able to invest his funds at the higher rate of interest. 
nary income equal to that portion of the original debt that is discharged without actual payment by the taxpayer, in our case, $\$ 180,000$.

To treat T's transaction im this manner seeins both simple and logical. It has the benefits of comporting both with fundainental incoine tax concepts and with one's intuitive sense of what T's treatinent should be: a capital loss on his bad investment, coupled with ordinary incorne from his decreased obligations.

\section{B. Exceptions to the General Rule}

\section{Inclusion of the Unpaid Debt in Amount Realized}

Unfortnnately, imputation of imcome to $T$ as the result of the cancellation of T's indebtedness is not always so simple. Both case law and section $108^{91}$ coinplicate the result and make generalizations impossible. The Service ${ }^{92}$ and the courts ${ }^{93}$ have leeld that a taxpayer who disposes of property subject to a nonrecourse mortgage in excess of the property's value does not realize ordinary income from the discharge of indebtedness, but inerely includes the debt in his anount realized.

The idea that gain on the disposition of overly mortgaged property results im an increased amount realized instead of ordinary income from the discharge of indebtedness was first enunciated in Lutz \& Schramm Co. v. Commissioner ${ }^{94}$ There, the taxpayer placed a $\$ 300,000$ mortgage on property subsequent to his purchase. The property declined im value and was later transferred in satisfaction of the mortgage. The court reasoned that since the taxpayer liad in fact received $\$ 300,000$ cash as a result of owning the property, he had received that amount in exchange for the property and should include that anount in his amount realized. The court then explained that since the gam was realized from the sale or exchange of property, it could not be ordinary imcome realized from the discharge of indebtedness. ${ }^{95}$

This reasoning was followed in $R$. O'Dell \& Sons Co. v. Commissioner ${ }^{96}$ and Mendham Corp. $v$. Commissioner, ${ }^{97}$ where evidence indicated that the corporate taxpayer had similarly placed a mortgage on property subsequent to its acquisition. The courts spoke of a single transaction that was begun witl the loan and was completed by the

91. See infra notes $109-44$ and accompanying text.

92. Rev. Rul. 76-111, 1976-1 C.B. 214, 215.

93. See, eg., Millar, 577 F. 2 d at 214-16; Woodsam, 198 F. 2d at 359; Delman, 73 T.C. at 30; Tufts, 70 T.C. at $769-70$.

94. 1 T.C. 682 (1943).

95. Id. at 688-89.

96. 8 T.C. 1165 , $a f f d, 169$ F.2d 247 (1948).

97. 9 T.C. 320 (1947). 
transfer of property in satisfaction of the loan. They held that this transaction was a sale or exchange of the property for the loan proceeds. ${ }^{98}$ These cases distort the events that actually occurred. When a taxpayer borrows nnoney on a nonrecourse basis, he is not exchanging property for the loan funds. He is merely borrowing money and posting his property as security. Assuming he has some equity in the property after the loan, he is, under Crane, still treated as the owner; he has received nothing in exchange for his property because he is not exchanging his property, he is keeping it. If the taxpayer later decides to satisfy his obligation by returning the property to the lender, he will at that time exchange his property; and it is what he receives at that time, not what he has received at some other time, that determines his ainount realized on his disposition of that property. Just as rents received while the taxpayer owns property are not part of his amount realized on disposition, neither is money borrowed prior to disposition an amount realized on that disposition.

In spite of the problems with the above-mentioned cases, the Tax Court has recently rehed on these cases to justify its refusal to treat taxpayers in T's situation as being discharged from indebtedness. Indeed, even though the courts in Lutz \& Schramm and Mendham emphasized that the debt in these cases was not purchase money debt, but was actual cash received, the Tax Court has recently cited these cases as support for its view that no cancellation of indebtedness results on the transfer of property in satisfaction of a purchase money nonrecourse obligation..$^{99}$

In light of the weakness of the above cases on their own facts, their extension to others (i.e., purchase money debt) is unwarranted. Where the debt is a purchase inoney obligation financed by the seller, the borrower never receives any cash, either before or at the time of disposition. The rationale of the above cases, that the taxpayer had received casli in exchange for his property, simply cannot apply to a purchase money obligation.

In situations involving personal liability as opposed to nonrecourse debt, there is both judicial and regulatory authority for the proposition that a taxpayer who transfers property in satisfaction of his obligation has an amoumt realized only equal to the fair inarket value of his property. ${ }^{100}$ Any recourse debt that is cancelled in excess of the

98. 8 T.C. at $1167-68, a f f d, 169$ F.2d at $248-49 ; 9$ T.C. at 324.

99. Tufts, 70 T.C. at $763-66$; Millar, 67 T.C. at 660.

100. Treas. Reg. $§ 1.1017-1(b)(5)$ (1956). "Whenever a discharge of indebtedness is accomplished by a transfer of the taxpayer's property in kind, the difference between the amount of the obligation discharged and the fair inarket value of the property transferred is the amount which may be [treated as debt that has been discharged]." Id. See also Umited States v. Hall, 307 F.2d 
property's value is not an amount realized in exchange for the property, and the cancellation produces ordinary income. Although the explicit authority for extending this result to property transferred in satisfaction of nonrecourse debt is limited, the logic behind so doing is not.

\section{Lack of Personal Obligation \\ a. Personal Liability Imputed by Crane}

Another reason that courts have given for refusing to find discharge of indebtedness when a taxpayer returns property subject to a nonrecourse mortgage is that the taxpayer never had any personal obligation in the first place, so he can have no personal obligation from which to ever be discharged. ${ }^{101}$ This theory is exemplified by, and appropriate in, a case such as Collins $v$. Commissioner. ${ }^{102}$ There, a taxpayer gave a nonrecourse note secured only by property worth substantially less than the face anount of the note. The taxpayer argued, and the court found, that the note had never created a personal liability and that Collins had never really agreed to do more than transfer the mortgaged property to the lender. ${ }^{103}$

Where a taxpayer incurs what appears to be a liability to pay cash, but that liability is nonrecourse and is secured at the outset by property worth far less than the face amount of the debt, there is in fact no seinblance of personal debt ever created. It is clear $a b$ initio that the debt will not be paid in cash, but that the secured property will be returned. The critical distinction between Collins and a case such as Tufts is that where the value of the mortgaged property exceeds the nonrecourse debt at the time the debt is created, the taxpayer has equity in the property. Crane has nade it clear that in such a situation the taxpayer should be treated as having incurred a debt that he will treat as a personal obligation. ${ }^{104}$ When that obligation that was at soine time the equivalent of a personal liability is discharged, the extinguishinent of a personal liability inust be recognized. This discharge of the personal liability simply should not be equated with something that was never more than an obligation to give a certain piece of property.

\section{b. Timing of the Discharge: Realization}

There is one troubling problein with the above-suggested distinction between cases such as Tufts and Collins. While a taxpayer will

238, 242 (10th Cir. 1962); Bialock v. Commissioner, 35 T.C. 649, 660 (1961); L.D. Coddon \& Bros. v. Commissioner, 37 B.T.A. $393,398-99$ (1938).

101. Delman, 73 T.C. at 32-33.

102. 22 T.C.M. (CCH) 1467 (1963).

103. Id at 1471.

104. Crane, 331 U.S. at 14; see supra text accompanying note 32. 
treat a nonrecourse obligation as his personal debt as long as he lias equity in the property, as soon as the property declines in value below the amount of the mortgage, the taxpayer no longer has equity in the property and no longer can be expected to treat his obligation as a personal one. If the courts or Service were to take account of this fact, then the moment the value of the property sinks below the amount of the mortgage would be the moment when the owner should be deemed to have disposed of the property; after that time, lie should no longer be permitted depreciation on the property, or any other deductions granted the owner of property. ${ }^{105}$

The time of the taxpayer's actual transfer of the mortgaged property, the focus in Tufts, might indeed be irrelevant. If a taxpayer is treated as the purcliaser and owner of inortgaged property only because it is assumed that he will pay the mortgage, ${ }^{106}$ then, when it becoines apparent that lie will not pay the mortgage, not only does he have no personal obligation, but he also has no way to justify being treated as the owner of the property, and nay therefore be treated as liaving disposed of the property. Arguably, the true disposition of property occurs at the instant the fair market value of the property declines below the amount of the mortgage. ${ }^{107}$

The possibility of this treatment is attractive: a taxpayer is treated as having a personal obligation because he has an equity interest in property; when the equity disappears, so does the personal obligation, and so does any investment the taxpayer may liave in the property. Neither the Service nor the courts, however, have suggested such an approach, probably because it would present substantial administrative problems and because it seems inconsistent with the concept of realization. Mere appreciation or depreciation in the value of property does not justify current taxation. ${ }^{108}$ Instead, whatever tax consequences that may accompany a property's increase or decline in value generally must await actual disposition of that property.

If, as appears to be the case, the consequences of the decline in value of mortgaged property are to await the actual disposition, then

105. C.f. Estate of Franklin v. Commissioner, 544 F.2d 1045, 1048-49 (9th Cir. 1976) (limited partner without equity in property and unable to demonstrate that purchase price was at least approximately equal to fair market value was not entitled to a distributive share of the depreciation or interest deduction for such property).

106. E.g., Rev. Rul. 69-77, 1969-1 C.B. 59.

107. If this were the case, the taxpayer would be treated as disposing of the property at the instant its value goes below the mortgage, so that the amount realized would be the same whether judged as equal to the property's value or equal to the mortgage. The most important result would be to deny depreciation deductions to holders of overly mortgaged property. Since excessive depreciation deductions would not be permitted $a b$ initio, there would be none to recapture upon the "disposition."

108. Eisner, 252 U.S. at 207. 
the courts and the Service have at least been focusing on the proper time of taxing the property holder; but that very fact underscores the impropriety of the inethod of taxation they have employed. If $T$ is treated as the owner of the property until he actually disposes of it, then his basis continues to include the amount of the mortgage. The assumption that $\mathrm{T}$ will pay the inortgage is obviously necessary to the continued treatment of $\mathrm{T}$ as an owner with depreciable interest. Thus, unless $T$ is treated as having disposed of property when it declines in value below the nonrecourse debt, $\mathrm{T}$ will be treated as having an obligation that he will treat as a personal obligation until the time of his actual disposition. When $T$ disposes of the property, the realization occurs; and all the tax consequences, includimg both the decline in value of the property and the decrease in T's debt, may properly be taken imto account. To say that $T$ has no debt discharged when lie transfers his property is thus to either deny the initial validity of Crane or to ignore the concept of realization of income through discharge of indebtedness. It seeins too late in the gaine to do either.

\section{The Adjustment-of-Purchase-Price Exception to the General Rule}

Even assuming that $\mathrm{T}$ has his debt discharged at the time he disposes of his property, there are still further coinplications. Income from discharge of mdebtedness is subject to substantial restrictions incorporated into section 108. ${ }^{109}$ That section defines "indebtedness of the taxpayer" to imclude "any indebtedness . . . subject to whicl the taxpayer holds property." "110 The section specifies certain circuinstances under which discharge froin indebtedness is to be excluded from gross incoine, and at least one of those exceptions is of arguable relevance to $T$ in our hypothetical. This exception, embodied in section 108(e)(5), states that if a solvent and nonbankrupt taxpayer incurs a purchase inoney debt that is subsequently reduced, the reduction of the debt "shall be treated as a purchase price adjustment."111

\section{a. Legislative History}

While this exception might seein on the surface to govern T's treatment, the history of the section indicates that it should not. The legislative history of P.L. 96-589, which brought $\$ 108(\mathrm{e})(5)$ into being, indicates that the exception is applicable when "the seller of specific property reduces the debt of the purchaser that arose out of the

109. Bankruptcy Tax Act of 1980, Pub. L. No. 96-589, 94 Stat. 3389.

110. I.R.C. \& 108 (d)(1)(B) (Supp. IV 1980).

111. I.R.C. \& 108 (e)(5) (Supp. IV 1980). 
purchase."112 The committee report explains that the provision is meant to apply where the seller reduces the amount due from the purchaser pursuant to an agreement subsequent to the sale and "does not apply when the debt is reduced because of factors not involving direct agreements between the buyer and the seller."113

Obviously when T's debt is reduced, that reduction is not the result of any agreement between $T$ and the seller to lower the purchase price or to reduce T's debt. Indeed, in order to complete his purchase of the property and to retain the property $\mathrm{T}$ must, absent some supplemental agreement, pay the full $\$ 380,000$ of outstanding nonrecourse debt. T may satisfy his obligation to the seller by returning the property worth $\$ 200,000$ rather than by completing the cash purchase; but this reduction im T's obligation did not result from negotiations between the buyer and seller. Instead, it resulted from the very nature of nonrecourse debt and from market factors beyond the parties' control.

Where section 108(e)(5) apphes, it requires that the taxpayer's adjusted basis be reduced to reflect reduction in his purchase price. The reduction in basis must be simultaneous with the reduction in T's purchase price. In the type of case anticipated by Congress, there will be a supplemental agreement or renegotiation that reduces the amount the taxpayer must pay to retain the property, and the date of that agreement will be the date of the purchase price adjustunent. In T's case there is no direct agreement between the seller and $T$ to reduce the purchase price. Instead, T's debt is simply reduced as the property that secures the debt declines in value. Were the mere reduction in T's debt sufficient to require adjustment to the purchase price of the asset, then such adjustment would in T's case be required continuously as the asset declined in value. Indeed, since depreciation deductions are based on adjusted basis, it is conceivable that daily adjustınents of purchase price and corresponding daily adjustments in basis and allowable depreciation would be necessary. Such adjustments would be practically impossible. That they would be required were the 108(e)(5) exception to apply supports the argument that this section does not apply to T's situation.

\section{b. Judicial History}

It is apparent that section 108(e)(5) is not intended to govern T's situation not only from the section's legislative history, but also frown the judicial history of the "adjustinent of purchase price exception" to the general rule that discharge of indebtedness for less than the face

112. S. REP. No. 1035, 96th Cong., 2d Sess., 16 (1980), reprinted in 1980 U.S. CODE CONG. \& AD. NEws 7017, 7030, 7031 [hereinafter cited as S. REP. No. 1035].

113. Id. at 16-17. 
amount produces income. Section 108(e)(5) appears to be a codification of a case law exception that draws its roots from Bowers $v$. Kerbaugh-Empire Co. ${ }^{114}$ In that case, the taxpayer borrowed money and agreed to repay the borrowed funds in German marks. The number of marks to be repaid was fixed at the time of the loan. At the time of repayment, the German mark was worth substantially less than it had been at the time of borrowing, and the taxpayer was able to repay the loan with marks worth several hundred thousand dollars less than the original amount it had borrowed. Since, however, the borrowed money had been invested in a transaction that resulted in a total loss, the Court stated that "the mere diminution of loss is not gain, profit, or mcome," 115 and held that since the entire transaction had resulted in a loss, the taxpayer did not have gross income when, in effect, it was merely able to minimize its loss by discharging its debt for an amount, in U.S. dollars, substantially less than it had borrowed. ${ }^{116}$

Even though Kerbaugh-Empire has fostered the "adjustment of purchase price" exception that now appears as section 108(e)(5), it has not fared well as judicial precedent. It has been distimguished or disregarded in many cases dealing with income from the discharge of imdebtedness. ${ }^{117}$ When faced with a situation where the value of purchased property had declined and the seller agreed to accept less than the face amount of the debt in discharge of the purchase money mortgage, the courts have noted not merely that the overall transaction had not produced any gam to the taxpayer, but have avoided relying on Kerbaugh-Empire by also noting that, because the potentially taxable transaction arose out of the purchase of property, any tax consequence should await the disposition of that property. ${ }^{118}$ The courts apparently have been under the impression that while the taxpayer might derive some economic benefit from the reduction of his debt, that benefit simply mirrored the economic detriment he had suffered as his property decreased im value. Because the tax consequences of this economic detriment could not be realized until the taxpayer sold the property, the courts have deemed it inappropriate to require realization of the corresponding benefit before that time. By requiring the taxpayer to adjust the purchase price of his property (thus reducing the property's basis)

114. 271 U.S. 170 (1926).

115. Id. at 175 .

116. Id.

117. See infra text accompanying notes 137-40; see also Bittker \& Thompson, supra note 86, at $1162-65$.

118. See, e.g., Helvering v. A.L. Killian Co., 128 F.2d 433, 434-35 (8th Cir. 1942); Kirsch v. Commissioner, 115 F.2d 656, 658 (7th Cir. 1940); Fulton Gold Corp. v. Commissioner, 31 B.T.A. 519, 521 (1934); but see Fifth Ave.-Fourteenth St. Corp. v. Commissioner, 147 F.2d 453, 456 (2d Cir. 1944) (corporate taxpayer realized taxable mcome by buying its mortgages at less than face value). 
rather than to recognize incoine immediately, the courts have deferred realization of the gain aspects of the transaction until the loss aspects were realized-at the time of disposition.

i. Deferral of Income Justification For the Exception. The justifcation for the "adjustment of purchase price" exception, to defer income until realization of loss, does not apply to a taxpayer, such as the ones in Tufts, or $\mathrm{T}$ in our hypothetical, who transfers his property in satisfaction of the debt. The inapplicability of this justification is probably best expressed by the Supreine Court's opinion in Helvering $v$. American Chicle Co. ${ }^{119}$ In that case, the Court pointed out that if a taxpayer purchases property on credit and retains the property after he has paid the debt, there can be no gain because there has been no completed transaction. ${ }^{120}$ The Court noted, however, that in the case before it there was no evidence that the taxpayer still retained the purchased property and, as a result, the Court refused to apply the purchase price adjustment exception. ${ }^{121}$ The need to defer realization of income until the taxpayer's disposition of the property and his accompanying realization of loss is irrelevant to a taxpayer such as $\mathrm{T}$, whose discharge of indebtedness is the result of his disposition of the property, because when that is the case, gain and loss must coine at the same time (the time of disposition), without the need for any special exception to the general rules. ${ }^{122}$

In addition, the judicial history of the exception, like its legislative history, also indicates that the "adjustment of purchase price" exception is a narrow one-to be applied only when the purchaser and seller actually reduce the outstanding debt in negotiations as a result of the property's decline in value. ${ }^{123}$ There are no such negotiations in T's case; and it would be both unnecessary and illogical to hold that a taxpayer such as $T$ is merely adjusting the purchase price of his property, when he disposes of that property because he was unwilling to pay the purchase price of $\$ 380,000$.

119. 291 U.S. 426 (1934).

120. Id. at 429.

121. Id. at 430. The Court stated:

When a taxpayer gets money by issuing an obligation which he later discharges for less than its face, the transaction is completed, because money need not be sold or exchanged to be 'realized' . . . . But if he buys property by an obligation in the form of a bond, note, or the like, and if it remains in kind after the debt is paid, there can be no 'gain.' Id. (quoting 65 F.2d 454, 455 (2d Cir. 1933)).

122. But see Nutter v. Commissioner, 7 T.C. 480,483 (1946) where the purchase price adjustmeut exception was applied to a taxpayer who satisfied his debt by transferring the mortgaged property to the seller-creditor.

123. See, eg., Commissioner v. Coastwise Transp. Corp., 71 F.2d 104, 106 (1st Cir.), cert. denied, 293 U.S. 595 (1934). 
ii. Release of Assets Justification For the Exception. Another judicial justification for the "adjustment of purchase price" exception is that if a taxpayer retams property subject to a nonrecourse mortgage and the mortgage is discharged at less than its face value, the taxpayer cannot currently recognize income because there is no "release of assets previously subject to the obligation." 124 This focus on the release of assets steins from the Court's implication in Kirby Lumber that (1) debt discharge income must be accompanied by an increase in the taxpayer's net worth, and (2) unless the debt discharge frees up assets previously offset by the liability, there can be no real imcrease in the taxpayer's net worth.

The relevant cases have involved taxpayers who acquired property subject to a nonrecourse mortgage and then discharged the mortgage at less than face value. ${ }^{125}$ In each of these cases, the taxpayer had retained the nortgaged property, and the court decided that payment of the mortgage at less than face value did not produce discharge of imdebtedness income, but imstead worked a prospective reduction in the taxpayer's basis. As im the other "adjustment of purchase price" cases, the taxpayer im each of these cases still owned the property, and the desire to prevent realization of income until disposition of the property may have been the motivating force behind the court's actions. It would seem that the presence of this desire alone is enough to dispel the thought of the applicability of the release of assets justification to Tufts or to our hypothetical.

In each case the mortgage was included in the taxpayer's basis, and the fair market value of the property exceeded the debt at all times. Nonetheless, im one of these cases, Fulton Gold Corp. v. Commissioner ${ }^{126}$ the Tax Court explained that the taxpayer liad never incurred personal hability, but had "merely satisfied an encumbrance on property im which it had an equity, and there was no release of assets 'previously offset by the obligation." "127 The court concluded that because there was no personal liability, there was "no release of assets;" and since there was no "release of assets," there could be no income from the discharge of indebtedness. In that case, however, the mortgaged property was itself an asset previously offset by the mortgage it secured; and satisfaction of the inortgage obviously released that asset from its encumbrance, increased the taxpayer's net worth, and should liave resulted in imcome to the taxpayer.

124. Fulton Gold, 31 B.T.A. at 521.

125. Hotel Astoria v. Commissioner, 42 B.T.A. 759 (1940); Fulton Gold, 31 B.T.A. 519 (1934); Stanley Corp. of Am. v. Commissioner, 12 T.C. 1122 (1949); Ernst Kern Co. v. Commissioner, 1 T.C. 249 (1942).

126. 31 B.T.A. 519 (1934).

127. Id. at 521. 
As an initial matter, Fulton Gold ignores the teaching in Crane, where the Court said that if property is worth more than the debt to which it is subject, any discharge of imdebtedness would be considered by the taxpayer as a discharge of personal indebtedness. ${ }^{128}$ Where, as in Tufts or our hypothetical, the value of the property is less than the amount of the debt, discharge of the debt through disposition of the property could not "release" any assets other than the mortgaged property disposed of, and could not increase the taxpayer's net worth. Arguably, since the taxpayer's net worth is not increased by his disposition of the property, there could be no income from the discharge of indebtedness. As explained, the disposition may result in the current "release" of only the disposed-of property, but the disposition is also the occasion for realization of the earlier decline in the nonrecourse debt, which necessarily accompanied the decline in value of the subject property. ${ }^{129}$ Only if a taxpayer holds property worth less than the nortgage and satisfies the mortgage at less than face value while retaining the property may the purchase price adjustment rationale of Fulton Gold be appropriate, because there has still been no realization.

\section{c. A Suggested Application of the Adjustment of Purchase Price Exception}

i. Amount of Gain upon Disposition. If courts were to hold that a taxpayer's return of property in discharge of a nonrecourse obligation in excess of the fair market value of the property works a reduction of the purchase price, that reduced price must be reflected in the taxpayer's basis. The taxpayer who transfers his property would realize gam equal to the excess of his amount realized over his basis as so adjusted. In our example, T's new basis would be $\$ 120,000(\$ 400,000$ original basis, less $\$ 100,000$ adjustments for depreciation, less $\$ 180,000$ reduction in purchase price). His gain on the disposition would be $\$ 80,000$ ( $\$ 200,000$ amount realized less new basis of $\$ 120,000)$.

ii. The Ambiguous Character of the Gain. To state the amount of T's gain is not to end discussion of this issue, however, for the character of that gam must still be determined. Legislative history of the most recent ainendments to section 108 indicates that Congress intended such gain to be at least partially characterized as ordimary income. Indeed, the report of the Senate Finance Committee, in discussing the amendments, states that "the rules of the bill are intended to carry out the Congressional intent of deferring, but eventually collecting within a reasonable period, tax on ordinary income realized from debt dis-

128. Crane, 331 U.S. at 14; see supra text accompanying note 32.

129. See supra text accompanying notes 105-09. 
charge." 130 Unfortunately, the wording of the amendinents does not make clear whether that intent has been effectuated in the case of purchase price adjustments of depreciable property (an adjustment that merely lowers the basis of a nondepreciable capital asset would, of course, result ouly in added capital gains on the sale or exchange of the asset).

Simce the adjustment of purchase price exception would result in increased gain on the sale or exchange of property, that gam will be governed by either section 1250 or, if it is section 1245 recovery property, by section 1245 . As noted, section 1250 is imtended to recapture gain as ordinary income to the extent that the gain is the result of depreciation adjustments in excess of those that would have been made under the straight-line method. ${ }^{131}$ The application of that section to a situation imvolving a purchase price adjustment under $108(\mathrm{e})(5)$ is unclear. The potential problem lies in determining how much of the gain is the result of depreciation adjustments in excess of those that would have been made under the straight-line method; and this depends on how much depreciation would have been allowable under the straightline method. ${ }^{132}$ If the appropriate original cost basis from which to compute the allowable straight-line depreciation includes the full nonrecourse debt, then the aunount of depreciation that would have been taken under the straight-line method is, of course, substantially more than the amount of straight-line depreciation that would have been taken using, as a starting point, a cost basis that did not include that part of the nonrecourse debt that was never actually paid.

There is an analogous basis adjustment provision that should provide guidance. Section 108(c) provides that, in certain cases, a taxpayer need not recognize what would otherwise be incoine from the discharge of indebtedness if he elects to reduce his basis in certain depreciable assets; and section 1017(d)(2) specifically provides that if the asset whose basis is reduced is governed by section 1250 , then, for purposes of determining how much depreciation would have been allowed under the straight-line method, it is the new reduced basis rather than the original cost basis that governs.

In other words, to determine how 1nucli gain is recaptured as ordinary income on the sale or exchange of section 1250 property whose basis was reduced by the appreciation of section 1017 reduced-basis property, one must determine how much depreciation would have been allowed under the straight-line inethod had the basis of the property been reduced $a b$ initio. Any depreciation in excess of that amount is

130. S. REP. No. 1035, supra note 112 , at 10 (emphasis added).

131. See supra notes $72-76$ and accompanying text.

132. See § 1250(b)(1). 
recaptured. Thus, if $T$ had section 1250 property with an original basis of $\$ 400,000$, assuming a 20 -year useful life and no salvage value, $T$ would deduct $\$ 20,000$ per year depreciation under the straight-line method. If, after five years, his basis were reduced by $\$ 180,000$ pursuant to a section 1017 (d) adjustment, his new basis would be $\$ 120,000$ $(\$ 400,000$ less $\$ 100,000$ adjustments for depreciation less $\$ 180,000$ section 1017 basis reduction). Section 1017(d)(2) specifies that only that the amount of depreciation that would have been taken using the straight-line method from an original basis of $\$ 220,000$ ( $\$ 400,000$ less $\$ 180,000$ section 1017 adjustment) can escape recapture. In our hypothetical, straight-line depreciation would have produced $\$ 55,000$ in adjustments over the five years $(1 / 20$ of $\$ 220,000$ per year for five years). When the property is sold or exchanged for $\$ 200,000, \$ 45,000$ of the gain represents excess depreciation $(\$ 100,000$ actually taken less the $\$ 55,000$ that would have been allowed) and is recaptured as ordinary income.

Unfortunately, while the Code specifies this treatment where section 1017 basis adjustments are involved, it does not address the issue when the basis reduction is the result of a purchase price adjustment under section 108(e)(5) rather than the result of an election to reduce basis under section 108(c). The absence of specific direction would not appear to represent Congressional intent that the resnlt be different in the case of a section 108(e)(5) basis reduction, especially in light of Congress' desire "[t]o insure that the debt discharge ainount eventually will result in ordinary income (and cannot be converted to capital gain)." 133 Instead, the absence of specific direction on the treatment of basis reduction as the result of a purchase price adjustment may simply be the result of madvertence. In light of the clear Congressional intent to recapture excess depreciation as ordinary income, it would seem appropriate to apply the principle of section 1017(d)(2) to a basis reduction that occurs as the result of an adjustment of purchase price.

The language of section 108(e)(5) provides an additional reason for viewing the appropriate straight-line depreciation as only the amount that could have been deducted from an original basis that did not include the unpaid debt. That section, unlike section 1017, does not speak of a reduction of basis, but speaks instead of an adjustment to purchase price. Once the adjustment is made, then, the property is to be treated as if it were purchased for the lower amount. Since the original basis from which to compute appropriate depreciation is cost, and since the cost of property is obviously the amount for which the property was purchased, it seems clear that the principle enunciated in sec-

133. S. REP. No. 1035, supra note 112, at 11. 
tion $1017(d)(2)$ is, if anything, more clearly applicable to a section 108(e)(5) adjustment.

One possible problem with this result is that the only early case that considered a similar question held that where debt discharge was determined to result in a purchase price reduction, that reduction was only prospective. In Blackstone Theatre Co. $v$. Commissioner ${ }^{134}$ the basis of depreciable property was reduced because a nonrecourse obligation secured by the property was satisfied at a discount. The Commissioner argued that the basis adjustment should be retroactivc, but the court disagreed. The Blackstone Theatre court, legitimately concerned that such a retroactive adjustment would affect depreciation allowances for earher years, requiring amended returns for each of those earher years, and creating additional problems if some of those earher years in which depreciation had been computed from the higher basis were barred by the statute of limitations. Fortunately, the abovesuggested approach for determining what constitutes excess depreciation for purposes of section 1250 presents none of the problems feared by the court in Blackstone Theatre. The application of section 1250 to excess depreciation has no effect on any prior year's income and would require no amendments to prior returns. It merely determines the character of the gain on sale, in the year the sale occurs. Where, as in Tufts and in our hypothetical, the gaim has none of the characteristics of capital gain and where there is no reason, either in administrative convenience or judicial or legislative history, to interpret section 1250 in such a way as to allow more than the minimal amount of capital gain, the treatment of section 1250 that is suggested above is the only reasonable one.

If the property were governed by section 1245 rather than section 1250 , the result would be simple. With his reduced basis, $T$ would have $\$ 80,000$ of gam when he disposes of the property. Since his depreciation adjustments exceed the amount of his gain, all the gain would be ordinary income. ${ }^{135}$

\section{The "Overall Loss" Approach of Kerbaugh-Empire}

As stated earher, while treatment of the debt discharge as a reduction in purchase price would result in some ordinary income for $\mathrm{T}$, it is nonetheless not the treatment intended by section 108(e)(5). ${ }^{136}$ Instead of renegotiating the purchase price, $T$ simply discharges his obhgation to pay that price when he returns the property to the seller; and it is this discharge of T's $\$ 380,000$ indebtedness with property worth $\$ 200,000$

134. 12 T.C. 801 (1949).

135. See supra text accompanying notes 78-81.

136. See supra text accompanying notes 109-29. 
that results in T's incoine. The final potential obstacle to this realization of income is the "overall loss" concept of Kerbaugh-Empire. Kerbaugh-Empire might seem to indicate that since T's purchase of the property produced an overall loss, his relinquishment of the saine property should not result in gain. ${ }^{137}$ The continuing viability of the Kerbaugh-Empire approach is, however, questionable at best. ${ }^{138}$

Although Kerbaugh-Empire was distinguished, rather than overruled in Burnett v. Sanford \& Brooks ${ }^{139}$ and United States v. Kirby Lumber Co. ${ }^{140}$ the Court in both cases seeined to deny the significance of Kerbaugh-Empire's "overall loss" approach. In both cases the Court reasoned that taxes are determined on an annual, rather than a transactional, basis. The fact that an entire transaction resulted in a net loss did not prevent the Court in either case from deciding that the taxpayer had realized soine incoine from that transaction in the year that incoine was generated. ${ }^{141}$ Accordingly, even if Kerbaugh-Empire's "overall loss" approach was applicable to our liypothetical, its application would not preclude the inclusion of income from the discharge of T's debt. All that Kerbaugh-Empire could possible inean is that if borrowed funds are directly traceable to an activity that produced a loss, and if the loss from the activity was greater than the gain from the taxpayer's discharge of indebtedness, then the overall transaction has resulted in a net loss, and the tax consequences should reflect that loss, rather than a net taxable gain.

In our hypothetical, prior to disposition, T's tax balance sheet shows a loss of $\$ 100,000$ ( $\$ 100,000$ depreciation deducted without any offsetting incorne). To require $T$ to recognize a net gain of $\$ 80,000$ $(\$ 180,000$ debt discharge income less $\$ 100,000$ capital loss) would merely require $T$ to show a net loss of $\$ 20,000$ (the cash actually invested) rather than a loss of $\$ 100,000$ from the transaction as a whole. Neither the letter nor the spirit of Kerbaugh-Empire would be violated by the inclusion of a net of $\$ 80,000$ of incoine to reach a net tax result that reflects the net economic result of a $\$ 20,000$ loss.

137. 271 U.S. at 175; see supra text accompanying notes 115-16 for a statement of the overall loss approach and the apphication of this approach in Kerbaugh-Empire.

138. See, e.g., Bittker \& Thompson, supra note 86, at 1162-65.

139. 282 U.S. 359 (1931).

140. 284 U.S. 1 (1931).

141. 282 U.S. at 364; 284 U.S. at 3. Indeed, in Sanford \& Brooks, the Court stated that:

The net result of the two years, if combined in a single taxable period, might still be a loss; but it has never been supposed that that fact would relieve [the taxpayer] from a tax on the first, or that if affords any reason for postponing the assessunent of the tax . . . to ascertain more precisely whether the final outcome of the period, or of a given transaction, will be a gain or loss.

282 U.S. at 364. 


\section{Other Section 108 Exceptions}

To say that a taxpayer's return of property subject to a mortgage im excess of the property's fair market value gives rise to discharge of imdebtedness income may not always be accurate even if none of the above exceptions apply. Section 108 contaims a number of provisions that enable a taxpayer to defer the recognition of his debt discharge income. While none of these would apply to $T$ in our hypothetical or to the taxpayer in Tufts, they nonetheless may apply to other situations.

Section 108(a)(1)(A) allows a taxpayer going through bankruptcy to elect to reduce certain favorable tax attributes in lieu of currently recognizing debt discharge imcome and section 108(a)(1)(B) provides a similar election to imsolvent taxpayers. Fimally, sections $108(a)(1)(C)$ and $108(\mathrm{c})$ allow certaim taxpayers who are neither bankrupt nor insolvent to elect to reduce their bases in certain depreciable property they own, and thereby defer immediate recognition of debt discharge income. This last exception is available only with respect to debt incurred by a corporation or by an individual in connection with property used in his trade or business. ${ }^{142}$ Simce the taxpayers in Tufts and in our hypothetical incurred their debt im connection with investment property, the section 108(a)(1)(C) exclusion would be unavailable to them, but it would be available to busmess taxpayers in analogous situations.

Indeed, it is probably the presence of the above opportunities for the taxpayer to avoid current recognition of income that has kept the Service from arguing that the transfer of property subject to nonrecourse debt im excess of fair market value gives rise to the cancellation of imdebtedness. To the extent that the bankruptcy or insolvency exceptions would be applicable, however, deferral of debt-discharge imcome has both congressional approval and the appeal of simply giving assistance to those who need it; and it would appear to be the exception for solvent taxpayers using trade or business property that the Service would most like to avoid. While section 108 would not provide a way out for the solvent real estate investor, it would provide an escape from current imcome for solvent businesses. ${ }^{143}$ As an imitial matter, it is likely that the decrease in revenue that results from the extension of capital gains treatment to all taxpayers disposing of overly mortgaged property outweighs any imcrease in revenues that may result from the demial of section 108 treatment to those taxpayers who nnight otherwise take advantage of it. In any event, Congress was well aware, when it cnacted section 108, that some solvent businesses would take

142. I.R.C. $\S 108(d)(4)(A)$ (Supp. IV 1980).

143. See, eg., Delman, 73 T.C. at $32-40$. 
advantage of its provisions. To grant the benefit of those provisions to those for whom they were intended and simultaneously to deny the benefit of capital gains treatment to those for whoin it was not intended seems the logical choice. ${ }^{144}$

IV

\section{Application of the TaX Benefit and Discharge of INDEBTEDNESS RULES TO VARIOUS SITUATIONS}

This Part examines several potentially significant variations of the general fact pattern that has formed the basis for the foregoing discussion.

\section{A. Sale at a Gain}

In Tufts, the taxpayer's basis in the property he relinquished was in excess of both the property's fair market value and the amount of the nonrecourse debt to which the property was subject. Thus, when his amount realized was limited to the fair market value of the property, a loss was incurred, and the question addressed so far in this Article has been whether there is any income realized in addition to that capital loss. In many situations, however, the taxpayer will not suffer a loss on his disposition of mortgaged property, even though that property inay have substantially declined in value. Often, the taxpayer will have

144. It is possible that the Service's failure to attempt to treat the income upon disposition of overly encumbered property as debt-discharge income stemmed from concerns about how that income might be treated when generated by a partnership rather than by an individual. Most tax shelters, including the one in Tufts, are marketed as partnerships, and this characterization has, until recently, posed substantial problems for anyone attempting to determine the consequences of the discharge of partnership debt. Fortunately, these problems have been laid to rest. The first concern centered on the provisions in scction 108 that allow deferral of debt discharge income by a bankrupt or insolvent taxpayer. See, e.g., Ginsburg, supra note 2, at 734-37; W. MCKEE, W. Nelson \& R. Whitmire, Federal Taxation of Partnerships and Partners If 9106[3][b] (1977 \& Supp. 1982). If a partnership's only asset is the encumbered property, the partnership will be insolvent at the time of its disposition of that asset. If the insolvency or bankruptcy exception were applied to the partnership, no current (or, indeed, future) income would be generated, even though the individual partners had realized substantial tax benefits and might well be solvent. Section 108(d)(6) specifies that the exceptions to current inclusion of income apply at the partner levels rather than to the partnership. So long as the individual partners remain solvent and out of bankruptcy, the partnership's imsolvency is irrelevant under § 108. I.R.C. § 108(d)(6) (Supp. IV 1980).

The other potential problem with treatment of partnership debt was also eliminated recently. I.R.C. $\$ 752$ (b) (1976) treats a reduction of a partnership's habilities as a distribution (generally nontaxable) of money from the partnership to the partner, to the extent of each partner's sliare of the decreased debt. There had been concern that the requirement of $\S 752(\mathrm{~b})$ to treat a reduction in partnership debt as a distribution of cash meant that the debt reduction could not also be treated as income from the cancellation of indebtedness (taxable to the partners, to the extent of each partner's allocable share). That concern has been put to rest, simce the new law makes it clear that the discharge of partnership debt is treated as income to the partners. S. REP. No. 1035, supra note 112 , at 21 . 
taken depreciation deductions in excess of the real decline in value of his property. When this occurs, the taxpayer's basis will have been reduced below the property's fair inarket value, and the taxpayer will realize a gain on his disposition of the inortgaged property. The question then becoines: How 1nuch gain is realized?

If the facts of the basic hypothetical are changed so that T's property declines in value from $\$ 400,000$ to $\$ 310,000$, then $T$ will still choose to transfer the property worth $\$ 310,000$ to the seller rather than pay a $\$ 380,000$ inortgage. When he does so, his basis will be $\$ 300,000$, and he should realize a $\$ 10,000$ long term capital gain (excess of $\$ 310,000$ amount realized over $\$ 300,000$ adjusted basis). Since his original debt was $\$ 380,000$, and since he satisfied that debt by returning property worth $\$ 310,000$, T will also have $\$ 70,000$ of ordinary income from the discharge of that debt.

A tax benefit analysis of this situation would begin with the acknowledgment that $T$ has paid only $\$ 310,000$ of his $\$ 380,000$ debt. Of the $\$ 70,000$ of unpaid debt, one quarter $(\$ 17,500)$ has been deducted by way of depreciation and should produce ordmary income when it goes unpaid. The remaining $\$ 52,500$ of unpaid debt would increase T's gam on disposition by effectively reducing his basis froln $\$ 300,000$ to $\$ 247,500$. T would thus have $\$ 45,000$ ( $\$ 310,000-\$ 17,500-\$ 247,500)$ of gain on his transfer of the property. Since the depreciation taken in excess of that which would have been allowed under the straight-line method ( $\$ 100,000$ was actually taken; $\$ 82,500$ (25\% of the $\$ 330,000$ original basis, excluding the $\$ 70,000$ unpaid debt) would have been allowed under the straight-line method) is represented by the $\$ 17,500$ already accounted for, this remaining gain would not be recaptured by section 1250.

As noted, the same result could be reached by simply eliminating from T's basis the $\$ 70,000$ of unpaid debt. T's basis at disposition would then be $\$ 230,000$ ( $\$ 400,000$ origimal cost basis, less $\$ 100,000$ adjustment for depreciation, less $\$ 70,000$ of unpaid debt). T's gain on disposition would be $\$ 80,000$ ( $\$ 310,000$ amount realized less $\$ 230,000$ adjusted basis). Simce T's origmal cost basis should have included only the $\$ 20,000$ cash paid and the $\$ 310,000$ debt actually paid, allowable depreciation under the straight-line inethod would have been only $\$ 82,000$ ( $25 \%$ of $\$ 330,000) ; \$ 12,500$ of T's gain is the result of excessive depreciation (he took $\$ 100,000$ of depreciation) and will be recaptured as ordinary income. If the property were subject to section 1245, all income on the disposition up to the full $\$ 100,000$ depreciation taken would be ordinary income.

Neither the Service nor the courts have taken either of these approaches. They have instead held that in the above situation, T's 
amount realized is $\$ 380,000$, the full amount of the nonrecourse debtso that he has only a $\$ 70,000$ capital gain and no ordinary incone. ${ }^{145}$ Such failure to bifurcate the character of T's gain may be simple, but, insofar as it fails to recognize the real source of T's gain and gives favorable tax treatment to $\$ 70,000$ of gain that is deserving of none, it is also overly simplistic.

\section{B. Third Party Lender}

Throughout the discussion of our hypothetical it has been assumed that the property has been financed by the seller. It is, of course, quite possible that the financing may come from a third party. If that is the case, the taxpayer incurs his obligation to that lender and, if he defaults or transfers the property to the lender in discharge of that obligation, he still has incoine from the discharge of his indebtedness, subject to section 108.

The one difference between the case of a third-party lender and a seller-lender is that in the former case the tax benefit rule would not appear to be applicable. If $\mathrm{T}$ borrows money from a third party to pay the seller, he has, im effect, purchased the property for cash. The seller has received cash for the property, and when $T$ depreciates that property, his depreciation deductions represent amounts actually paid by him (or on his behalf). If he later fails to repay his loan, the fact that the depreciation deductions represent actual amounts paid does not change. That these amounts were paid with borrowed money does not effect this deductibility, for the amounts were, nonetheless, paid. ${ }^{146}$ If $T$ pays back less than the face amount of his loan, he has debt discharge incoine, but the mere fact that he has used the funds from that subsequently discharged debt to pay a deductible expense does not invoke the tax benefit rule. The deducted expense was paid; the amount was not returned to $\mathrm{T}$; therefore, the tax benefit rule is inapplicable.

\section{Third Party Purchaser}

\section{The Discharge of Indebtedness Rule}

Instead of returning his mortgaged property to the seller in discharge of the nonrecourse debt, the taxpayer may simply transfer the property, still subject to the mortgage, to a third party. Indeed, such was the case in both Tufts and Crane. That the transfer of the property is to a third party rather than to the lender should not change the

145. E.g., Millar, 577 F.2d at 215-16; Woodsam, 198 F.2d at 358-59; Delman, 73 T.C. at 29-30; Tufis, 70 T.C. at 770.

146. E.g., McAdams v. Commissioner, 198 F.2d 54, 55 (5th Cir. 1952) (payment with borrowed funds is nonetheless payment for income tax purposes.) 
amount of income the taxpayer has frown the discharge of his indebtcdness. The taxpayer incurs a debt when he receives the property, and he discharges his obhgation when he transfers that property. That he does not transfer the property in satisfaction of the debt should not preclude debt discharge income, because the transfer of the property does nonetheless work a discharge of his obligation to pay the debt; and it is this discharge that generates cancellation of indebtedness income. Thus, where the transfer is to a third party, the taxpayer would still realize a capital loss on the transfer equal to the excess of his adjusted basis over his amount realized (the fair market value of the property). His income from the discharge of indebtedness would equal the excess of that original debt over the amount he actually pays in discharge of that debt (i.e., the fair market value of the property plus any cash payment). His capital loss would still accurately reflect the excess of the decline in value of his property over the depreciation allowed; and his ordinary income would accurately reflect the amount of the liability from which he has been released during the time he held the property.

One change that would result frown the transfer of the property to a third party would be that it would become even inore clear that the "adjustment of purcliase price" exception of section 108(e)(5) would not apply. Since, as noted, that exception applies to renegotiations of price between the purchaser and the origmal seller of the property, it can have no application when the transfer is not to the origmal seller but to a third party. ${ }^{147}$

\section{The Tax Benefit Rule}

If the Court does not choose to recognize ordinary income from the discharge of indebtedness in this third-party purchaser case, the tax benefit rule slould then govern. ${ }^{148}$ As explamed, T's tax benefit was the $\$ 100,000$ of depreciation deductions. He lias actually paid $\$ 20,000$ cash for the property. When $T$ transferred the property back to the seller, he had paid not only $\$ 20,000$ casl, but also had held $\$ 200,000$ (fair market value) worth of property, so that at least some of his depreciation deductions represented actual amounts paid for the property. If $\mathrm{T}$ transfers the property to a third party, he will have paid only the $\$ 20,000$ cash to the seller for the property. He will have deducted $\$ 100,000$ of depreciation on the assumption that it would be paid out to the seller. Under the simplest application of the tax beneflt rule, since $\$ 80,000$ of the $\$ 100,000$ actually deducted does not get paid, $T$ will have $\$ 80,000$ of income.

147. S. REP. No. 1035, supra note 112 , at 15-16.

148. Since Tufts itself involved a third-party lender as well as a third-party purchaser, the tax benefit rule cannot apply to that case; see supra text accompanying notes 145-46. 
The expanded version of the tax benefit rule suggested earlier ${ }^{149}$ produces a result that may mirror the actual economic results of the transaction more clearly than any approacli so far discussed. When $T$ has deducted $\$ 100,000$ of his $\$ 400,000$ cost basis, he has deducted onefourth of each separate dollar of cost. Thus, his $\$ 100,000$ of depreciation represents the deduction of one-fourth of his $\$ 20,000$ cash outlay $(\$ 5,000)$ and one-fourth of the $\$ 380,000$ debt $(\$ 95,000)$. If $T$ pays none of the debt, then he has deducted $\$ 95,000$ that le does not pay, and he has $\$ 95,000$ of ordinary imcome under the tax benefit theory. Once $T$ accounts for this $\$ 95,000$ of ordinary income, he has, in effect, given back the tax benefits he realized from $\$ 95,000$ of the loan.

Of the remaining $\$ 285,000$ of loan proceeds, $\$ 200,000$ are accounted for in T's amount realized. Since T receives no cash, his amount realized would be zero, were it not for that $\$ 200,000$ debt of which he is relieved. However, smce $T$ is relieved of an obligation to satisfy his nonrecourse debt (he owes the lesser of $\$ 380,000$ casly or the property worth $\$ 200,000$ ), his amount realized includes that $\$ 200,000$ of debt relief. By imcluding that $\$ 200,000$ in his amount realized, he changes a $\$ 300,000$ loss (excess of adjusted basis of $\$ 300,000$ over amount realized of 0 ) into a $\$ 100,000$ loss ( $\$ 300,000$ less $\$ 200,000$ amount realized). Thus, $T$ has so far accounted for $\$ 295,000$ of the $\$ 380,000$ nonrecourse debt.

When $T$ transfers the property, he still has a $\$ 100,000$ capital loss (adjusted basis of $\$ 300,000$ less amount realized of $\$ 200,000$ ). This loss is the result of 'T's mclusion of the $\$ 380,000$ debt in his cost basis. That debt has not been paid. However, $\$ 295,000$ of the debt lias been accounted for elsewhere $(\$ 95,000$ ordinary imcome and $\$ 200,000$ amount realized). To the extent that T's $\$ 100,000$ loss is the result of his tax use of the remaining $\$ 85,000$ of unpaid debt, the tax benefit rule would generate income corresponding to the loss. Thus, $\$ 85,000$ of the $\$ 100,000$ capital loss would be cancelled out by the $\$ 85,000$ of corresponding capital gains. T would be left with a $\$ 15,000$ capital loss to go with his $\$ 95,000$ of ordinary imcome.

Although confusing, this last analysis is the one that comes closest to puttimg $T$ in the position lie would have been in had the unpaid nonrecourse debt been excluded from ' $T$ 's cost basis $a b$ initio. If foresight had been available at the time of T's purchase, so that he knew he would not pay the $\$ 380,000$ nonrecourse debt, then his cost basis would have been $\$ 20,000$ (the cash paid). Over the five years he lield the property, T could have deducted only $\$ 5,000$ of depreciation. When he transferred the property and received nothing for it, le wonld have had

149. See supra notes $65-77$ and accompanying text. 
a $\$ 15,000$ capital loss. T would be out his $\$ 20,000$ cash payment and the net tax result over the five years would have been $\$ 5,000$ in ordinary deductions and a $\$ 15,000$ capital loss. If the above tax benefit analysis is adopted, $\mathrm{T}$ would have included the debt in his cost basis and would have taken $\$ 100,000$ of ordmary deductions during his fiveyear holding period. When he disposes of the property, $T$ will have $\$ 95,000$ of ordinary income, and a $\$ 15,000$ capital loss. When the $\$ 95,000$ of income is netted with his $\$ 100,000$ depreciation deductions, $\mathrm{T}$ is left with the saine net of $\$ 5,000$ ordmary deductions and a $\$ 15,000$ long term capital loss.

\section{Transfer to Third Party with Boot: Crane Revisited}

\section{Significance of the Boot}

The analysis in the previous Section produces an appealing result when the mortgaged property is transferred to a third party and the taxpayer receives no consideration from that third party other than the purchaser's taking subject to the mortgage. If, however, the third party transferee pays even a small amount of cash or some other form of consideration, the language of Crane makes the outcome less clear. The Court in Crane stated that a mortgagor "who sells the property subject to the inortgage and for additional consideration, realizes a benefit in the amount of the mortgage as well as the boot."150 This statement resulted from the Court's concern "with the reahty that an owner of property mortgaged at a figure less than that at which the property will sell, must and will treat the conditions of the mortgage exactly as if they were his personal obligations."151 In effect, the faet that the purchaser paid Ms. Crane what was then a substantial amount ${ }^{152}$ in addition to taking the property subject to the mortgage was evidence that the property was worth more than the inortgage. Since the property was worth more than the inortgage, the amount of the nonrecourse inortgage was included in Ms. Crane's amount realized.

Where there is evidence, as there was not in Crane, ${ }^{153}$ that the value of the property is less than the amount of the mortgage, the presence of boot must take on a different hight. A court must deterinme from all the evidence, including both the existence of boot and any other evidence of the property's fair market value, whether the property was worth more than the debt to whieh it was subject, so that the taxpayer would indeed treat the debt as his personal obligation. Direct

150. 331 U.S. at 14.

151. Id.

152. Id. at 3, 4 .

153. Id. at 11-13. 
evidence concerning the value of the property should be given primary weight, but the existence of boot is not, of course, irrelevant. If the amount of boot is insubstantial, as in Tufts, ${ }^{154}$ its presence is accordingly insubstantial evidence regarding the value of the property. If there is substantial boot, then its presence inay well be payinent for the taxpayer's equity in the property, and it may indicate that the property had value in excess of the inortgage.

Boot inay be received for something other than the taxpayer's equity, however; and its presence does not necessarily indicate that the taxpayer had any equity. Aside from the property, the taxpayer has another asset that he transfers along with that property-the inortgage terms. If the nonrecourse inortgage is in excess of the property's value, then that mortgage is likely not to be paid. If, however, the mortgage is not due until solne future time, a purchaser may pay cash in order to take the property subject to the inortgage and thereby hold the property until the inortgage is due. In a sense, the purchaser may pay cash for the temporary use of the property. Where that is the case, there is, of course, no evidence that the property is worth more than the debt and no evidence that the property will sell at a figure in excess of the mortgage. Instead, there is evidence only that the taxpayer is selling soinething in addition to his property-his favorable mortgage terms.

\section{The Discharge of Indebtedness Rule}

The taxpayer who sells his property to a third-party purchaser and receives boot still realizes income from the discharge of his indebtedness. The excess of the face aunount of the debt over the property's fair market value represents debt that is discharged when the property is transferred. His amount realized for the property is still only the fair market value of the property; but the taxpayer in this case receives two separate iteins that together constitute that anount realized. First, since the mortgage is not due until some future date, the taxpayer gets relieved only of an obligation to return the property at that future date; and the present cost of that obligation inust be discounted to reflect the fact that it is not yet due. Thus, when a taxpayer is relieved of an obligation to pay $\$ 200,000$ (or to return property worth $\$ 200,000$ ) in a year, the alnount of benefit he receives is only about $\$ 175,000$, the present cost of that obligation (in other words, the taxpayer could imvest $\$ 175,000$ today and have enough to satisfy his $\$ 200,000$ obligation at the end of one year). If the taxpayer is reheved of his obhigation to pay $\$ 200,000$ in one year and is also given $\$ 25,000$ cash, his total amount

154. Tufts, 651 F.2d at 1059 . 
received is still only $\$ 200,000$. The cash boot merely represents the discounted value of the debt relief when the debt is not currently due.

Where the mortgage is not deferred, but is payable currently im monthly imstallments, the taxpayer may still receive boot im exchange for favorable mortgage terms, rather than for an equity in the property. For example, a $4 \%$ mortgage of $\$ 380,000$ would require lower total payments than would a $15 \%$ mortgage of $\$ 300,000$. A taxpayer who holds property worth $\$ 300,000$ subject to a four percent, $\$ 380,000$ mortgage may receive cash when lie transfers the property subject to the mortgage, even though he obviously has no equity in the property. In this case, even though he has no equity in the property, the taxpayer is likely to treat the obhigation as a personal one, and, as a result, the full amount of the debt should be included in his amount realized on disposition. Nonetheless, the taxpayer should not receive capital gains treatment. He would still have (1) ordinary income equal to the excess of the face amount of the debt over the value of the property, and (2) a capital loss equal to the excess of his adjusted basis over the value of the property.

The taxpayer who sells property subject to a low imterest mortgage sells two things: (1) the property, and (2) the favorable loan terms. The amount lie receives for the property obviously does not exceed the value of that property; and the difference between his adjusted basis and that value will be a capital gam or loss (subject to sections 1250 and 1245).

To the extent that the entire debt plus any boot received exceeds the fair market value of the property, the taxpayer is paid not for the property, but for the favorable loan terms. The taxpayer has and sells a presumably valuable contract, one that allows him to retain the benefit of borrowed funds while paying less than market interest. While the sale of contract riglits may at times produce capital gams, it often does not. The sale of a contract right will produce capital gains only when the contract right gave the taxpayer "an estate' in . . . or an 'encumbrance' on ... or an option to acquire an interest in ... property which, if itself held, would be a capital asset."15s When the taxpayer sells "a naked contract right" that creates no equitable estate in property, he does not sell a capital asset. Obviously, a taxpayer who sells a loan agreement did not liave an equitable imterest in any property represented by that agreement. The only possible property associated with the agreement is the loan proceeds, but money is not property for tax

155. Commissioner v. Ferrer, 304 F.2d 125, 130 (2d Cir. 1962) (citations omitted); Commercial Solvents Corp. v. United States, 427 F.2d 749, 756 (Ct. Cl. 1970). See generally Eustice, Contract Rights, Capital Gain and Assignment of Income-The Ferrer Case, 20 TAX L. REv. 1 (1964). See also Valler v. United States, 454 F.2d 1120, $1121-23$ (8th Cir. 1977). 
purposes. ${ }^{156}$ It is surely not a capital asset, and one simply cannot claim to enjoy the capital gams treatment associated with the sale of property when all he is selling is, at most, a temporary interest in money. ${ }^{157}$

In most cases, a taxpayer who disposes of overly mortgaged property will receive no boot. Where there is boot, it will generally not be substantial. If there is substantial boot, then it still does not change the facts that (1) the taxpayer's capital gain or loss will be the difference between his adjusted basis and the fair market value of the property; and (2) the difference between the face amount of the debt and the value of the property will still be ordimary income.

\section{$\mathrm{V}$ \\ The Tax Benefit Rule vs. The Discharge of INDEBTEDNESS RULE: WHICH TAKES PRECEDENCE? \\ A. Precedence in the General Case}

T's disposition of his mortgaged property generates income under both a tax benefit theory and a discharge of indebtedness theory. These two theories, however, result in income that differs in both amount and character. Even the most expansive application of the tax benefit rule to our hypothetical would produce only $\$ 45,000$ of ordinary income and $\$ 35,000$ of capital gain when $T$ disposes of the property. ${ }^{158}$ By contrast, under the suggested application of the discharge of indebtedness rule of Kirby Lumber, T would liave $\$ 180,000$ of ordinary income and a $\$ 100,000$ capital loss. ${ }^{159}$ If $\mathrm{T}$ is a $50 \%$ bracket taxpayer, application of the tax benefit rule would result in an increase in tax due of only $\$ 29,500$ (50\% of the $\$ 45,000$ ordimary income and $20 \%$ of the $\$ 35,000$ capital gain). On the other hand, the cancellation of indebtedness approach generates an additional $\$ 90,000$ of tax liability (50\% of the $\$ 180,000$ ordinary imcome) and a long term capital loss which inay or may not be currently deductible. ${ }^{160}$

156. E.g., Treas. Reg. § 1.83-3(e) (1978).

157. It may at first blush appear that if a taxpayer sells property subject to a low interest nonrecourse mortgage, the favorable mortgage represents not merely the right to use money, but an equitable interest in the underlying property itself. That is not the case. If the property is worth $\$ 300,000$ and is subject to a low interest mortgage in excess of that amount, there could be no interest in the property worth more than $\$ 300,000$. To argue that a purchaser inay pay $\$ 300,000$, the value of the property, for the fee, and would pay an additional amount for soine other interest in the same property would be senseless. If the purchaser pays the fair market value for the property, any amount paid (and any amount realized by the seller) in excess of that fair market value is paid for something other than any interest in the property.

158. See supra text accompanying notes $72-77$.

159. See supra text accoinpanying notes 89-93.

160. See I.R.C. §§ 165(f), 1211 (1976 \& Supp. IV 1980). 
The different results produced by the two theories, both of which would appear to govern the Tufts problem, require that a determination be made as to which should be given precedence. While both rules produce more reasonable results than does the approach of the Fifth Circuit in Tufts, both logic and equity require that the discharge of indebtedness rule take precedence and that incoine otherwise generated by the cancellation of indebtedness should not be excluded froin imcome simply because the indebtedness produced a tax benefit. In our hypothetical, T received $\$ 380,000$ worth of property in exchange for his proumise to pay $\$ 380,000$ at some time in the future. Had the property not been depreciable, he would have received no tax benefits from incurring the debt, and the tax benefit rule would not apply to the cancellation of that debt either while $T$ held the property or when he disposed of it. Instead, T would inerely have income generated by the cancellation of his indebtedness (subject to the exceptions noted above ${ }^{161}$ ).

Since $T$ has in fact purchased depreciable property, he has enjoyed depreciation deductions that would not have been available absent a basis increased by the nonrecourse debt. The fact that $T$ has enjoyed deductions in addition to acquiring land certainly provides no reason for lessening the tax hability to which he would be subject had he not been afforded those deductions. Because of the deductions, the apphcation of Kirby Lumber is supplemented by the application of the tax benefit rule. Clearly, this supplemental remedy should not act to reduce the amount of $\operatorname{tax} \mathrm{T}$ would otherwise be required to pay. ${ }^{162} \mathrm{Ac}-$ cordingly, where $\$ 180,000$ of ordinary income is currently produced by the apphication of Kirby Lumber, all of that incoine is taxable.

Of course, the tax benefit rule produces results which are both more equitable and inore logical than those proposed by either the Tax Court or the court of appeals in Tufts. Were the court to decide that the discharge of indebtedness rule does not apply to a taxpayer such as $\mathrm{T}$, the tax benefit rule should be applied. This Section inerely demonstrates that where both rules are available, the discharge of indebtedness rule should take precedence.

161. See supra text accompanying notes 142-44.

162. If debt has been incurred in a situation where the taxpayer's assets have not been increased, then the enjoyment of a tax benefit produced by the incurrence of the debt has been seen as necessary to the production of income from the cancellation of debt. E.g., Rev. Rul. 67-200, 1967-1 C.B. 15; Rev. Rul. 70-406, 1970-2 C.B. 16. Since T's debt was incurred for the purchase of property, and the delivery of that property increased T's assets, the additional presence of a tax benefit is unnecessary to the application of cancellation of indebtedness principles. 


\section{B. Precedence Where the Tax Benefit Rule Would Produce More Current Income: Section 108 Deferrals of Debt Discharge Income}

\section{Putoma and the Bankruptcy Tax Act}

A different confrontation between tax benefit principles and the treatment of incoine from the discharge of indebtedness may arise, however, when the tax benefit rule would produce current income in a situation in which section 108 would permit the deferral of incoine generated solely by cancellation of indebtedness. As explained, section 108 permits effective deferral of income from the discharge of indebtedness if the taxpayer is bankrupt or msolvent or if the debt is a qualified business debt and the taxpayer elects to reduce his basis in certain assets. ${ }^{163}$ Since there is no coinparable provision available to the taxpayer who recovers an amount that would produce income under the tax benefit rule, the question arises whether the taxpayer who has enjoyed a tax benefit may nonetheless take full advantage of section 108 by deferring the income he would otherwise recognize due to the cancellation of his indebtedness. Even where the tax benefit rule would produce more current income than the discharge of indebtedness rule because of the section 108 deferral, the latter should take precedence.

Although the question of whether section 108 may apply to the cancellation of a debt that produced a tax benefit when incurred has not been directly addressed, several courts have addressed the problem of whether other exceptions to Kirby Lumber take precedence over tax benefit principles. Prior to the Bankruptcy Tax Act, ${ }^{164}$ the cancellation of a corporation's debt by a shareholder-creditor had been viewed as a nontaxable ${ }^{165}$ contribution to capital by the shareholder under section 118. ${ }^{166}$ The Service had argued that to the extent the debt had produced a tax benefit, ${ }^{167}$ the cancellation of the debt produced income under the tax benefit rule in spite of section 118's general exclusion of contributions to capital from the corporation's gross incoine. The rule, however, had been well estabhshed that the exclusion from income provided by treating the cancelled debt as a contribution to capital took precedence over the tax benefit rule. ${ }^{168}$

The cases that gave priority to section 118 's exclusionary treatment

163. See supra text accompanying notes $143-44$.

164. Bankruptcy Tax Act, supra note 109.

165. I.R.C. 118 (1976 \& Supp. IV 1980).

166. Treas. Reg. \& 1.61-12(a) (1968).

167. For example, the corporation inay have benefited where the debt represented salary not paid, but already deducted, by the corporation. Putoma Corp. v. Commissioner, 66 T.C. 652, 66670, affd, 604 F.2d 734 (5th Cir. 1979).

168. E.g., Putoma, 66 T.C. at $666-70$, and cases cited therein. 
over the tax benefit rule took their cue from, and are comparable to, Helvering v. American Dental Co. ${ }^{169}$ In that case the Supreme Court decided that the creditor's cancellation of debt owed himself was a gift. ${ }^{170}$ The gift, by way of debt cancellation, did not generate ordinary income to the debtor-taxpayer in spite of the fact that the creation of the debt had produced a tax deduction. Although the courts failed to rely on the analogy, the results in the above cases coincide with the tax result that would have been produced by an actual cash gift or contribution to capital by the creditor followed by the debtor's use of the proceeds to satisfy the debt. The gift or contribution would not be taxable to the debtor; and the use of the donated amounts by the debtor to satisfy his accrued hability would result in the actual payment of the deducted amounts and would negate any need for the tax benefit rule. Since the debtor could have escaped tax by receiving a gift or contribution to capital and then paying the debt owed to the donor, there was no reason to treat the two transactions any differently than they would have been treated had they been separated.

In spite of these cases giving exclusionary treatment precedence over the tax benefit rule, Congress decided to change the result. The problem with the earlier result was not that the corporate debtor had deducted an amount that was never paid, but that the shareholder-employee, presumably a casl1-inethod taxpayer, had never in fact received the accrued salary due him and had never included that amount in his income. Had the creditor made a real contribution to capital and then received the salary due him, the corporate debtor's tax would not have been increased, but the shareholder-employee's tax would have been increased by the amount of salary he received. Instead, under the old rule, neither the corporation nor the shareholder-employee was required to include any annount in incoune when tle corporate debt was cancelled. Congress therefore decided to employ tax benefit principles to cliange the result. ${ }^{171}$

For the purpose of determining whether section 108 may override the tax benefit rule in our hypothetical situation, the nost noteworthy element of this change is the manner in which Congress chose to apply the tax benefit rule to the discharge of a debt to a shareholder-employee. As a result of the combination of the unpaid but deducted salary and the employee's failure to mclude that amount in his own income, Congress decided that tax benefit principles should apply. When they are applied, they do not necessarily result in the current inclusion of the deducted but unpaid amounts. Instead, because tax

169. 318 U.S. 322 (1943).

170. Id. at 331 .

171. Bankruptcy Tax Act, supra note 109, § 2(a). 
benefits result from the discharge of the corporation's debt, the tax benefit principle is applied to force the corporation to "account" for the debt discharged just as it would be required to account for any other debt discharge-by including the amount of debt discharged in income unless it may be deferred under some other provision of section $108 .{ }^{172}$

Where soine other provision of section 108 permits the deferral of otherwise includable debt discharge incoine, the tax benefit rule does not override that deferral. Instead, the rule requires that the cancellation of the debt result in income subject to possible deferral. Since, in the Tufts situation and in our hypothetical, the cancellation of indebtedness is accounted for under Kirby Lumber, the tax benefit rule is served whether the discharged debt be currently included or whether it be deferred as might be any other income from debt discliarge.

\section{Permanent Versus Temporary Deferral}

A separate line of cases dealing with corporate liquidations and not involving the discharge of indebtedness has held that the tax benefit rule generates incoine in spite of the existence of separate Code sections that appear to exclude the questioned amounts from income. ${ }^{173}$ These cases recognize that if an item has been deducted without having been spent, it must be accounted for when it becomes clear that payinent will never be made. In such cases, hindsight slows the original deduction to have been unwarranted, and the tax benefit rule has provided the only means to counter the benefit originally produced by that deduction.

In all the decided cases concerning the possibility of imposing tax liability under the tax benefit rule on a transaction seemingly exempted from tax by some other section (section 118 in the case of shareholder cancellation of debt; sections 332 and 336 in the other cases), the question has been whether a taxpayer who has enjoyed the benefit of a tax deduction without the corresponding burden of actual payment of the amount deducted could retain that windfall in perpetuity. If the tax

172. The Senate Report accompanying the bill gives the following example:

... assume a corporation accrues and deducts, (but does not actually pay) a $\$ 1,000$ liability to a shareholder-employee as salary, and the cash-basis employee does not include the $\$ 1,000$ in income. In a later year, the shareholder-einployee forgives the debt. Under the bill, the corporation must account for a debt discharge amount of $\$ 1,000$. If the corporation is insolvent or in bankruptcy, it inust apply the $\$ 1,000$ debt discharge anount to reduce tax attributes [just as any other bankrupt or insolvent taxpayer whose debt is cancelled]. If the debtor is a solvent corporation outside bankruptcy, it can elect to reduce basis of depreciable assets . . . by $\$ 1,000$ in lieu of recognizing $\$ 1,000$ of income in the year of discharge.

S. REP. No. 1035, supra note 112 , at 11.

173. E.g., Hillsboro Nat'l Bank v. Coinmissioner, 641 F.2d 529, 531 (7th Cir. 1981), cert. granted, 455 U.S. 906 (No. 81-485); Tennessee-Carolina Transp. Co. v. Commissioner, 582 F.2d $378,381,382$ (1978). 
benefit rule did not apply, the deducted but unpaid amount in those cases would never be included in the taxpayer's taxable income.

Such is simply not the case in our hypothetical, where the disposition of the mortgaged property gives rise to potential imcome from the cancellation of indebtedness. But for section 108(a), this imcome would be fully and currently included in T's gross income. Section 108(a) permits the deferral in certain circumstances of "any amount which (but for this subsection) would be includable in gross incoune by reason of the discharge ... of indebtedness." 174 Whether or not the cancelled debt qualifies for deferral under section 108 does not change the fact that the debt either has been or will be accounted for through the present or future generation of debt-discharge income. Unlike the decidcd cases, then, the tax benefit rule is not necessary to account for the inclusion of previously deducted amounts in our hypothetical or in the Tufts fact pattern. The only change that application of the rule could make is one of timing of income rather than actual inclusion of that income; but that change is simply not within the focus of the tax benefit rule.

\section{CONCLUSION}

This Article has focused on the treatment of a taxpayer who disposes of depreciable property subject to a nonrecourse mortgage in excess of the property's fair market value. It has suggestcd a number of possibilities. Each is subject to some uncertainties, and each may result in different treatment depending on who financed the property and on who is the transferee of the property. These complications are unavoidable. Prior to disposition, the taxpayer has enjoyed tax benefits (the result of the nonrecourse debt being included in basis) that turn out to be unrelated to reality. Instead of denymg these benefits $a b$ initio, the tax law can only attempt to make the taxpayer adequately account for them at some later time. So far, it has not done even this.

Most courts have suggested including the debt in the taxpayer's amount realized. This result provides capital gains treatment to taxpayers who have in fact suffered capital losses. The Fifth Circuit recognized the inequity in this approach, but unfortunately failed to suggest any viable alternative. Tufts simply ignored the fact that the taxpayer had received excessive tax benefits; and it provided him with still more undeserved tax benefits upon his disposition of the property.

This Article has suggcsted several approaches that more accurately

174. Section 108(a) speaks im terms of exclusion from gross income, but because the exclusion is accompanied by the loss of other favorable tax attributes, the result is a later increase in gross income equal to the amount currently excluded. The current exclusion of income combined with the later increase in income makes for actual deferral rather than exclusion of the imcome generated by the cancelled indebtedness. 
reflect both the reality of the transaction and the tax benefits previously received by the taxpayer. Application of the tax benefit rule would require the taxpayer to account for previous tax benefits to the extent they turn out to have been inappropriately granted in the first place. It would produce soine ordinary income upon the taxpayer's disposition of his property, but it would also produce limited capital gains, unless the property were transferred to someone other than the lender. Application of cancellation of indebtedness principles produces ordinary income and a capital loss. It mirrors the real decline in both the taxpayer's obligation and the property's value; but at the same time, it may allow certain taxpayers to defer recognition of any incoine until some later time.

None of the above approaches is perfect. The problem to which they are addressed does not lend itself to an easy solution. What is clear is that the approaches adopted by the courts to date create the most distortion, and are the least logical, of any of the possibilities. The approaches suggested above are admittedly less simple than the inclusion of nonrecourse debt in a taxpayer's amount realized. For simplicity, however, substitute both logic and equity. It is a substitution worth naking. 